\title{
"Rights" in the Federal Administrative State
}

\author{
Jerry L. Mashaw $\nmid$
}

It is a first principle of American constitutionalism that the ultimate non-violent protection of individual rights from governmental encroachment resides in an independent judiciary. A similar ideal of "judicial review" permeates American administrative law. In the end, the citizen, indeed any "person," it is thought, may call administrators to account in court and thereby protect his, her, or its rights. This Article explores a group of related developments that suggest the extremely fragile character of that judicial protection. These converging clusters of cases illustrate the basic dependence of the judiciary on the legislative and administrative branches of government for the very conception of law that animates judicial judgment. And, if that is true, then an activist state-a state that emphasizes the administration of social and economic life in pursuit of collective ends-will tend to redefine rights in ways that de-emphasize individual legal remedies. In such a state, the judiciary will ultimately adopt what I shall term here a "statist" conception of legal rights and legal personality, that is, a conception crucially dependent for its content on legislative definitions of public welfare and on the organizational imperatives of the state's administrative-governmental apparatus.

This story is hardly novel. The Supreme Court's ratification of state social legislation and of the New Deal signaled the jurisprudential rejection of the classical liberal ideal of an autonomous private domain of "property" and "liberty." And administrative law's attempted redefinition of individual rights in terms of procedural protections or substantive claims on "new property" perhaps never misled those who have consistently focused on the "inherent contradictions" of liberalism. ${ }^{2}$ Yet, it

$\dagger$ William Nelson Cromwell Professor of Law, Yale University.

1. The Court's invalidation of social legislation during the pre-New Deal era was premised on the notion that there existed a social compact, or unwritten constitution, which created legally cognizable natural rights reserved to the people within the private domain. See Corwin, The "Higher Law" Background of American Constitutional Law, 42 HARV. L. REV. 149 (1928). Beginning with Nebbia v. New York, 291 U.S. 502 (1934), the Court eroded these natural law boundaries on government action past recognition by approving crucial New Deal legislation, such as the Fair Labor Standards Act in United States v. Darby, 312 U.S. 100 (1941), the National Labor Relations Act in NLRB v. Jones \& Laughlin Steel Corp., 301 U.S. 1 (1937), and the Agricultural Adjustment Act in Wickard v. Filburn, 317 U.S. 111 (1942).

2. For examples of such critiques, see R. UNGER, KNOWLEDGE AND POLITICS (1975); R. UNGER, LAW IN MODERN SOCIETY: TOWARD A CRITICISM OF SOCIAL THEORY (1976); M. HORWITZ, THE 
seems useful to review how far we have moved in the 1970's, indeed since the mid-1970's, to consolidate a federal common law that emphasizes a statist conception of legal personality and legal rights. For it is essentially in this period that a conservative Supreme Court has rationalized and extended the jurisprudence of the activist state to make explicit conclusions that were merely implicit in earlier legal doctrine. Indeed, but a decade earlier, a quite different, individualistic and court-centered, federal jurisprudence might have been imagined to be the norm.

In looking at this particular period in American administrative law and then backward and forward to bracket it in related historical developments, I shall surely lapse into generalizations from particular examples that are, to say the least, deeply problematic. The reader should keep in mind, therefore, the motivation for this excursion. I am attempting to explain why certain doctrinal developments that seemed critically important in the early 1970's-indeed that seemed to provide the central images of rights in an increasingly administrative state-now seem the relics of a bygone era. I want, moreover, to offer an explanation that focuses, not on general political or social movements, or on shifts in the personnel and personal philosophies of the Supreme Court, but rather on the intellectual structure of our dominant conceptions of rights. From the perspective of the 1980's, we can see that it is these conceptions, in part legacies of the legitimation of the New Deal, that the jurisprudence of the 1960's and early 1970 's failed to displace.

\section{The Rights in Question}

Having apologized in advance, let me try to capture the essence of "rights" in American administrative law by discussing the Supreme Court's doctrinal approach to three categories of interests: (1) the right to participate in administrative decisionmaking, (2) the right to call officials to account in court for the legality of their actions, and (3) the right to sue to enforce liberty and property interests established, but only partially implemented or protected, by governmental entities. In American administrative law the doctrine elaborating these interests presents a distinctive vision of rights-holding and rights-definition, of the relationship between private persons and officials, and of the role of courts in shaping that relationship. For our present purposes the presentation of a pair of abstract and sharply contrasting conceptual approaches is sufficient to highlight the fundamental choices that the Court has made.

TRANSFORMATION OF AMERICAN LAW, 1780-1860 (1977); THE POLITICS OF LAW (D. Kairys ed. 1982); Kennedy, The Structure of Blackstone's Commentaries, 28 BUFFaLo L. REV. 205 (1979); Taylor, Deconstructing the Law, 1 YALE L. \& POL'Y REV. 158 (1982); Unger, The Critical Legal Studies Movement, 96 HARV. L. REV. 561 (1983). 
Consider first a model that shall be referred to as the "individualistic" conception of rights. Here citizen participation in public decisionmaking and official accounting for public decisions are available on demand from courts, which view statutes and regulations as but one source of public common law. From this perspective legislative and administrative lawmaking are meant to be integrated through judicial action into the set of property and liberty interests available to those who invoke the courts' jurisdiction. Participation and accounting rights inhere in the legal system's basic conceptions of property, citizenship, or legal personality. Judicial remedies largely constitute and independently structure the governing conception of law. Although legal rights and legal identity here obviously depend upon judicial action, the governing judicial norms are rooted in ideas of private ordering. Those ideas emphasize autonomy and consent, and they are "administered" by judges whose independent jurisdiction and status are both constitutionally assured and constitutionally limited.

The contrasting rights structure is one that permits participation only in aid of official action; calls officials to account for their official acts only to the extent that legislation establishes special processes for that purpose; and views legislation and its implementation as the province of non-judicial, public officials. Judicial jurisdiction is special, legislatively prescribed, and strictly construed. Private attempts to enforce the putative protections or benefits of public law by means of litigation are generally deemed inconsistent with the state's need for centralized administration to achieve public purposes. The "purposes of the state" provide both the central tenets of legal interpretation and the sources of previously unspecified legal norms. This model represents the "statist" conception of rights.

These abstract conceptions are not so much opposites as extreme tendencies in legal orders having similar institutions and material conditions. But the general tendency of the legal order is a powerful engine for shaping its development. To the extent that there is a recognizable legal order, it exists because we can identify some set of reasonably coherent general ideas that seem to underlie particular laws or legal decisions. In nonrevolutionary times, legal development involves analogical extension of those ideas. ${ }^{3} \mathrm{~A}$ legal order that views legislation, administration, and per-

3. In recent years emphasis on so-called "rules of recognition," cultural, psychological and other determinants of what we select as meaningful, has become commonplace, particularly within the social sciences and philosophy. For the social sciences, see C. GEERTZ, Local Knowledge: Fact and Law in Comparative Perspective, in LOCAL KNOWLEDGE: FURTHER ESSAYS IN INTERPRETIVE ANTHROPOLOGY 167 (1983); C. GEERTZ, Thick Description: Toward an Interpretive Theory of Culture, in THE INTERPRETATION OF CULTURES 3 (1973); C. GEERTZ, Deep Play: Notes on the Balinese Cockfight, in id. at 412 . In philosophy, work has centered around speech-act theory. See, e.g., J. SEARLE, SPEECH ACTS (1969); S. FISH, IS THERE A TEXT IN THIS CLASS? (1980). Quentin Skinner has applied speech-act theory to more social scientific themes. E.g., Skinner, Conventions and Understanding of Speech Acts, 20 PHIL. Q. 118 (1970); Skinner, Some Problems in the Analysis of Political Thought 
haps all of "public law" as "special," and that, therefore, analogizes from the "general" case of private ordering supported by judicial dispute resolution, will develop quite differently than a legal order that reverses the institutional attributes it considers "special" and "general."

\section{The Individualist Model}

The former, individualist legal order is almost perfectly exemplified by three cases reported in volume 397 of the United States Reports. These cases, all decided in early 1970 , crystallized a jurisprudence on hearing rights, ${ }^{4}$ standing, ${ }^{5}$ and private enforcement of public law ${ }^{6}$ that had been developing for at least a decade.

\section{A. Goldberg v. Kelly}

Goldberg ${ }^{7}$ concerned both the definition of property and the institutions through which particular property holdings are determined. Its narrow issue was whether the state may terminate certain welfare benefits before holding a hearing on the appropriateness of termination. Terminated welfare recipients claimed that the statutes and regulations, which allowed them a hearing only after the termination, deprived them of property without due process of law.

One obvious approach to this question would be to ask how the relevant legislation and regulations define the welfare claimants' interests and what processes they provide to adjudicate claims. Upon finding that the recipients' property interests, so defined, do not include continuation of payments pending resolution of disputes and that the state had employed the appropriate administrative process to determine eligibility, the Court would dismiss the case. But that, just as obviously, is not the Goldberg approach. Instead, the Court reached out to adopt Charles Reich's analogy of statutory to common law property. ${ }^{8}$ The special statutory limitations or restrictions on welfare property are submerged by the more general idea-emanating both from common law and many other statutory schemes-that holders of property may not be divested of their rights except by adjudication in a form resembling a civil trial.

The Court did not ignore the statutory origins of the property involved,

and Action, 2 POL. THEORY 277 (1974). For an application of these ideas to law, see Fiss, Objectivity and Interpretation, 34 STAN. L. REV. 739 (1982).

4. See Goldberg v. Kelly, 397 U.S. 254 (1970).

5. See Association of Data Processing Serv. Orgs. v. Camp, 397 U.S. 150 (1970) (ADAPSO).

6. See Rosado v. Wyman, 397 U.S. 397 (1970).

7. Goldberg v. Kelly, 397 U.S. 254 (1970).

8. See id. at 262 n.8 (citing Reich, Individual Rights and Social Welfare: The Emerging Legal Issues, 74 Yale L.J. 1245, 1255 (1965), and Reich, The New Property, 73 Yale L.J. 733 (1964)); id. at $265 \mathrm{n} .13$ (citing Reich, supra, 74 YALE L.J. at 1255). 
nor did it divest administrative jurisdiction. Nevertheless, it clearly integrated both the statutory scheme and the administrative process into an independent and more general conception of property and fairness-the constitutional common law of due process. Having used entitlements language in one section of the statute, Congress will not be heard to deny the customary implications of that language in another. Administrative implementation remained the norm, but agencies were required to treat individual claimants as rights-bearers whose claims had to be assessed before a (nearly) neutral tribunal.

\section{B. ADAPSO}

Association of Data Processing Service Organizations (ADAPSO) v. Camp reinterprets "standing" doctrine in a quite similar fashion. The petitioner objected to a ruling of the Comptroller of the Currency permitting national banks to sell their excess computer capacity in competition with its members. It invoked in support of its claim a statute prohibiting banks from engaging in non-banking activity. The Comptroller moved to dismiss the action on the ground that the statute in question was designed to protect the general integrity of the banking system and thus provided no right to competitors, such as ADAPSO's members, to be free from bank competition. Given that Congress had enacted no special statutes enabling competitors to attack his orders in court, the Comptroller argued that ADAPSO lacked standing to sue. ${ }^{10}$

Although the Comptroller's arguments tracked conventional standing doctrine, they did not prevail. The Supreme Court approached the case from the perspective of a general right to judicial review. The Comptroller thus put the question in the wrong way. The issue was not whether Congress had specifically intended to give ADAPSO a right to review. It was instead whether ADAPSO's members could be considered as "arguably within the zone of interests to be protected or regulated"11 by the relevant statute. If so, then they would lack standing to sue only if they were in fact unaffected by the Comptroller's action or Congress had specifically prohibited suits of the sort in question.

While suggesting that its redefinition of the right to call public officials to account emerged non-problematically from the Administrative Procedure Act, ${ }^{12}$ the $A D A P S O$ Court was instead crystallizing a common law of judicial review that viewed the right as general rather than special. Professor Jaffe had argued eloquently for such a presumptive right of

9. 397 U.S. 150 (1970).

10. Id. at 151 ; see $i d$. at 154 .

11. Id. at 153 .

12. Id. at 153-54 (citing 5 U.S.C. $\$ 702$ (amended 1976)). 
review in his 1965 treatise $^{13}$ and traced its common law origins to as early as 1902.14 The Court noted that "[W] trend is toward enlargement of the class of people who may protest administrative action."15 Henceforth, apparently, all statutes would be viewed as forming a part of that "trend," unless specific provisions were inserted to the contrary.

\section{Rosado v. Wyman}

Rosado $^{16}$ is less a part of the common intellectual baggage of contemporary lawyers than is Goldberg or ADAPSO, but it is no less important. There New York welfare recipients sued the State Commissioner of Social Services, claiming that New York had violated the United States Constitution and a federal statutory condition attached to federal grants-in-aid of state payments under the Aid to Families with Dependent Children (AFDC) program by failing properly to adjust its standard of need for purposes of computing welfare eligibility. The issue principally before the Court was whether the federal courts should retain "pendent" jurisdiction over the statutory claim after the constitutional claim that had formed the predicate for federal jurisdiction had been decided against the plaintiffs. The Court's decision that pendent jurisdiction could be maintained was an important strategic victory in the battle for "welfare rights," but two other issues, one of which was ignored by the Court, are of more interest to this discussion.

The first issue involves the basic theory of the plaintiffs' claim. The obligation that they sought to impose on New York involved a condition on the latter's acceptance of federal funds under Title IV of the Social Security Act. ${ }^{17}$ That New York owed an obligation to the United States not to violate this condition seems straightforward. But whence arose the claimants' right to enforce compliance? Their only relationship to the Title IV program was as recipients under a state statutory program that happened to be funded in part by federal funds.

A possible answer was 42 U.S.C. $\S 1983$, which provides a cause of action for deprivation of rights guaranteed under the Constitution or any federal statute. But this answer was both inappropriate and incomplete. It was inappropriate because it would have anticipated by ten years an interpretation of section 1983 that extends its reach beyond "civil rights"

13. L. JAFFE, JUdicial CONTROL OF ADMINistrative ACTION 336-53 (1965).

14. Id. at 339 (citing School of Magnetic Healing v. McAnnulty, 187 U.S. 94 (1902)).

15. 397 U.S. at 154 .

16. Rosado v. Wyman, 397 U.S. 397 (1970).

17. 42 U.S.G. $\$ 602(a)(23)(1976)$. 
legislation, ${ }^{18}$ and because section 1983 is never mentioned in Rosado as the basis for the plaintiffs' claims. It was incomplete because section 1983 itself provides no rights. ${ }^{19}$ The right must first be found in the Constitution or in a statute. Yet the Rosado Court seemed convinced beyond any need for discussion of these issues that third-party beneficiaries of federal legislation governing the conduct of state officials have a right to judicial enforcement of statutory obligations, provided that federal court jurisdiction (here pendent) exists.

Rosado is thus the heir of another 1960's case, J.I. Case Co. v. Borak, ${ }^{20}$ as well as an important companion to ADAPSO. Borak allows beneficiaries of federal securities legislation to enforce that legislation by means of an action for damages or an injunction when they are harmed by conduct violating the federal statute or regulations implementing it. Extending this form of third-party-beneficiary enforcement to federal grantin-aid programs means that when federal policies are implemented by state administrators, the ADAPSO presumption of reviewability applies. Rosado thus integrates the remedial system for grant-in-aid programs with the remedial system $A D A P S O$ establishes for federal legislation generally. Each system has at its core a presumption that judicial remedies are available whenever official actions adversely affect private interests.

This interpretation of Rosado is strengthened by the Court's explicit rejection of New York's claim that even if judicial jurisdiction potentially existed it had nevertheless been ousted by the primary enforcement jurisdiction of the Department of Health, Education, and Welfare (HEW). The Court recognized that there was a complex statutory and regulatory scheme for HEW determination of state non-compliance with federal conditions and for departmental withdrawal of federal support. It recognized further that a judicial finding of non-compliance and an order to the state to cease utilizing federal funds would have similar effects. ${ }^{21}$ But, the Court noted, citing $A D A P S O$, "We are most reluctant to assume Congress has closed the avenue to effective judicial review to those individuals

18. Maine v. Thiboutot, 448 U.S. 1 (1980).

19. It simply states:

Every person who, under color of any statute, ordinance, regulation, custom, or usage, of any State or Territory or the District of Columbia, subjects, or causes to be subjected, any citizen of the United States or other person within the jurisdiction thereof to the deprivation of any rights, privileges, or immunities secured by the Constitution and laws, shall be liable to the party injured in an action at law, suit in equity, or other proper proceeding for redress. For the purposes of this section, any Act of Congress applicable exclusively to the District of Columbia shall be considered to be a statute of the District of Columbia.

42 U.S.C. $\S 1983$ (1976 \& Supp. V 1981). This section is remedial in nature. See Monroe v. Pape, 365 U.S. $167,173-74$ (1961).

20. 377 U.S. 426 (1964).

21. Rosado v. Wyman, 397 U.S. $397,420-21$ (1970). 
most directly affected by the administration of its program."22 That there was a special administrative process to enforce state compliance did not, of itself, limit the general idea that the beneficiaries of federal statutory rights could enforce those rights in court.

\section{On the Margin of Volume 397}

Goldberg, ADAPSO, and Rosado, particularly the former two, were hailed as the fruition of historic trends in the jurisprudence of administrative law-trends towards openness, participation, accountability, and the protection of individual rights. The cases seemed to confirm the abandonment of distinctions between common law rights and statutory privileges that commentators recently had pronounced dead. ${ }^{23}$ Ideas of legal identity or personality were said to have matured to the point where we could now accept the inevitability of increased collective action without inhibiting, indeed while fostering, our historic sense that legal security-the rule of law-inhered in the ability to pursue judicial remedies for the invasions of individual rights. All that had been needed was a new vision of rights that included those important interests and protections that had been emerging for half a century in the fabric of federal statutes and regulations. ${ }^{24}$

In the early 1970's, these ideas were elaborated and extended, especially by the Courts of Appeals. Participation rights were confirmed with respect to a wide range of administrative actions affecting individual private interests and were even extended by analogy to arenas of administrative policy choice affecting the public at large. By 1975, Richard Stewart could describe the "reformed" view of administrative law as the "interest representation model"-something of a combination of pluralist politics and the forms of civil trial. ${ }^{25}$ Many of the paradigmatic instances of this model emerged from the Court of Appeals for the District of Columbia Gircuit. It, for example, invented "hybrid" rulemaking, ${ }^{28}$ which entailed hearings on contested issues of fact, and so limited ex parte contacts in rulemaking that it cast in doubt the legality of administrators taking policy advice from their own staffs, ${ }^{27}$ except in proceedings open to all inter-

22. Id. at 420 .

23. Van Alstyne, The Demise of the Right-Privilege Distinction in Constitutional Law, 81 HARV. L. REV. $1439,1445-49$ (1968).

24. J. Vining, Legal Identity: THE CoMing of AGE of PUblic LaW (1978).

25. Stewart, The Reformation of American Administrative Law, 88 HARV. L. REV. 1667 (1975).

26. Public Serv. Comm'n v. FPC, 487 F.2d 1043 (D.C. Cir. 1973), vacated and remanded, 417 U.S. 964 (1974); Mobil Oil Corp. v. FPC, 483 F.2d 1238 (D.C. Cir. 1973); International Harvester Co. v. Ruckelshaus, 478 F.2d 615 (D.C. Cir. 1973); Walter Holm \& Co. v. Hardin, 449 F.2d 1009 (D.C. Cir, 1971); see Williams, "Hybrid Rulemaking" Under the Administrative Procedure Act: A Legal and Empirical Analysis, 42 U. CHI. L. REV. 401 (1975) (discussing these and other "noticeand-comment-plus" cases).

27. See Hercules Inc. v. EPA, 598 F.2d 91 (D.C. Cir. 1978). 
ested persons.

The sources of these new participatory rights were obscure, but intriguing. To some degree they emerged as an articulation of ideas of "fairness" closely associated with conventional adversary proceedings. But more often they were linked to the need to produce an adequate record for appellate judicial review. ${ }^{28}$ Such review would be occasioned, of course, by the requests of these same participating private parties pursuant to broad statutory grants and liberal judicial interpretations of standing. In this way, presumptive judicial review was made more effective by increased participation. The two rights became mutually reinforcing aspects of a judicial campaign to broaden access to and increase the accountability of administrative processes.

For a time the requirement of "standing" seemed destined for oblivion. A lawsuit apparently concocted to seek out the boundaries of the expanded concept could not find them. ${ }^{29}$ Meanwhile, third-party-beneficiary suits of the Borak or Rosado type flooded, and were accepted by, the lower federal courts. ${ }^{30}$ Nor were the courts alone in exalting private rights at the expense of bureaucratic discretion. The Freedom of Information $\mathrm{Act}^{31}$ and the Privacy $\mathrm{Act}^{32}$ gave all citizens "property rights" in the information held by government bureaus. Amendments to the Administrative Procedure $\mathrm{Act}^{33}$ and to federal court jurisdictional statutes ${ }^{34}$ eliminated troublesome barriers to judicial review other than standing. And regulatory statutes enacted during this period almost inevitably included broad standing provisions; ${ }^{\text {ss }}$ immediate, "pre-enforcement" review of agency rules;" and often "citizens suit" clauses permitting any person to

28. See Ethyl Corp. v. EPA, 541 F.2d 1, 66-67 (D.C. Cir.) (en banc) (Bazelon, J., concurring), cert. denied, 426 U.S. 941 (1976).

29. United States v. Students Challenging Regulatory Agency Procedures, 412 U.S. 669 (1973) (SCRAP).

30. See Cannon v. University of Chicago, 441 U.S. 677, 730 (1979) (Powell, J., dissenting).

31. The Freedom of Information Act (FOIA), Pub. L. No. 89-554, 80 Stat. 383 (1966) (codified as amended at 5 U.S.C. $\$ 552(1982)$ ), requires federal agencies to make available to the public any written information in their possession unless specifically exempted.

32. The Privacy Act, Pub. L. No. 93-579, 88 Stat. 1897 (1974) (codified at 5 U.S.C. \& 552a (1982)), permits individuals on whom files are kept by federal agencies to participate in the use, review, and disposal of their files. For discussions of the Act, see Hanus \& Relyea, A Policy Assessment of the Privacy Act of 1974, 25 AM. U.L. REV. 555 (1976); Note, The Privacy Act of 1974: An Overview, 1976 DUKE L.J. 301.

33. Pub. L. No. 94-574, 90 Stat. 2721 (1976) (amending 5 U.S.C. §§ 702-703).

34. Id. (amending 28 U.S.C. $\$ \S 1331(\mathrm{a}), 1391(\mathrm{e})$ ).

35. E.g., Toxic Substances Control Act of 1976, 15 U.S.C. $\$ 2618$ (a) (1982) ("any person may file a petition for judicial review"); Consumer Product Safety Act of 1972, § 11, 15 U.S.C. § 2060 (1982) (conferring standing on "consumers and consumer organizations," as well as on aggrieved parties); Occupational Safety and Health Act of 1970, § 11, 29 U.S.C. $\S$ 660(a) (1982) (conferring standing on "[a]ny person adversely affected or aggrieved"); see $4 \mathrm{~K}$. DAVIS, ADMINISTRATIVE LAW TREATISE \& 24:4, at 221-22 (2d ed. 1983).

36. Sec Consumer Product Safety Act of 1972, § 11, 15 U.S.C. § 2060 (1982) ("Not later than 60 days after a consumer product safety rule is promulgated by the Commission . . . any consumer or 
enforce administrative regulations. ${ }^{37}$

\section{Something Happened}

I cannot identify the precise moment of the mid-1970's shift away from individualist and toward statist conceptions of rights. Indeed, it seems plausible to find the analytic and rhetorical potential for such a shift in cases like Goldberg, ADAPSO, and Rosado themselves. I will suggest as much somewhat later when I come to consider whether the volume 397 cases were part of a "trend," 38 as the Court suggested in ADAPSO, or were merely a wave in the more general trend toward statist legal ideology, perceptible since the 1930's. Nevertheless, the approach to the recognition and definition of the three rights we have been considering began to change.

\section{A. The Right to Participate}

Wayne Kennedy was a field representative in the Office of Economic Opportunity (OEO). He publicly charged that his supervisor, one Verduin, had offered a bribe, in the form of an OEO grant, to members of a community service organization. The supervisor removed him from the federal service, pursuant to the Lloyd-LaFollette (Civil Service) Act, which provided that Kennedy was removable only for "such cause as will promote the efficiency of the service." ${ }^{\text {s9 }}$ The Act provided Kennedy a right to an informal pre-termination hearing on the "good cause" issue before his station chief, in this case Verduin. Kennedy understandably objected to that procedure and requested instead a formal hearing before an impartial hearing officer. When the requested procedure was refused, Kennedy filed suit arguing that his due process rights under Goldberg had been violated.

In the leading opinion in Arnett v. Kennedy, ${ }^{40}$ fully subscribed to by only three Justices, Justice Rehnquist recognized that Kennedy's right to be removed only for "cause" was some sort of statutory interest. Yet, it was not in Rehnquist's view an interest recognizable as "property" for purposes of due process. He noted that

the very section of the statute which granted [Kennedy] that right . . . expressly provided also for the procedure by which "cause" was

consumer organization, may file a petition . . . for judicial review of such rule.").

37. The Clean Air Act Amendments of 1970, § 12(a), 42 U.S.C. $\$ 7604$ (a) (1976 \& Supp. V 1981), for example, state that "any person may commence a civil action on his own behalf . . . against any person... . who is alleged to be in violation of [any] standard or limitation under this chapter." Virtually every environmental statute passed since 1970 has a similar provision.

38. Association of Data Processing Serv. Orgs. v. Camp, 397 U.S. 150, 154 (1970).

39. 5 U.S.C. $\S 7503$ (1982).

40. 416 U.S. 134 (1974) (plurality opinion). 
to be determined, and expressly omitted the procedural guarantees which [he] insists are mandated by the Constitution.

Here the property interest which [Kennedy] had in his employment was itself conditioned by the procedural limitations which had accompanied the grant of that interest. ${ }^{41}$

Kennedy was advised that he had to take the "bitter with the sweet."12 Five members of the Court objected ${ }^{43}$ that this approach had been rejected in Goldberg and in other cases upon which Justice Rehnquist's opinion relied. Two of the five concurred ${ }^{44}$ in the judgment, however, on the ground that the Lloyd-LaFollette Act procedures were sufficient under the Goldberg formula. Yet within two years a majority of the Court, in Bishop v. Wood," subscribed to the view that "[a] property interest in employment can, of course, be created by ordinance, or by an implied contract .... Whether such a guarantee has been given can be determined only by an examination of the particular statute or ordinance in question." 46 The Bishop majority characterized as "remarkably innovative"17 the suggestions in one dissenting opinion that the existence of a property interest sufficient to require due process protection was a matter for independent judicial determination. The majority was committed to the proposition that there was no federal "common law" of property. ${ }^{48}$

Nor was this commitment limited to employment cases. In Paul v. Da$v i s,{ }^{49}$ the Court considered whether police circulation of respondent's name and photograph on a list of "active shoplifters" branded him a criminal without due process of law. (Davis had once been charged with shoplifting, but the charges were dropped prior to trial.) Justice Rehnquist, writing for the Court, held that there was no property or liberty interest in reputation. To be sure, numerous cases had suggested that reputation was a protected interest under the due process clause, but all those cases (save one) were explained away as involving reputational harm that aggravated the deprivation of some independent right guaranteed by state law. ${ }^{\text {so }}$

41. Id. at $152,155$.

42. Id. at 154 .

43. Id. at 164 (Powell \& Blackmun, JJ., concurring); id. at 206 (Marshall, Douglas \& Brennan, JJ., dissenting).

44. Id. at 164 (Powell \& Blackmun, JJ., concurring).

45. 426 U.S. 341 (1976). Justices Stevens and Powell formed this majority by joining the Chief

Justice and Justices Rehnquist and Stewart in this new approach to property interests.

46. Id. at 344-45.

47. Id. at 349 n.14.

48. Id.

49. 424 U.S. 693 (1976).

50. Id. at 699-712. 
The dissenters in Paul v. Davis ${ }^{51}$ were horrified both by the majority's cavalier treatment of precedent and by the implications of the ruling. To Justice Brennan,

The logical and disturbing corollary of this holding is that no due process infirmities would inhere in a statute constituting a commission to conduct ex parte trials of individuals, so long as the only official judgment pronounced was limited to the public condemnation and branding of a person as a Communist, a traitor, an "active murderer," a homosexual, or any other mark that "merely" carries social opprobrium. ${ }^{.2}$

Yet, by 1978 Justice Brennan himself could not locate property rights for due process purposes without the assistance of state law. When automobile dealers and their franchisees complained of arbitrary suspension of their right to locate or relocate dealerships in California, Justice Brennan replied that "General Motors had no interest in franchising that was immune from state regulation." ${ }^{\circ 3}$ And speaking of a stop order allegedly issued without the necessary constitutional safeguards, he continued, "The Board's notice served only to inform appellee . . . of this [state regulation] and to advise it of the status, pending the Board's determination, of its franchise permit applications." The "advice" of the Board was, of course, that appellees could not locate or relocate their business for up to eighteen months-advice, which, under the relevant statute, was given automatically and ex parte whenever any competitor requested it.

In the same Term the Court called an abrupt halt to the District of Columbia Circuit's insistence on "hybrid" rulemaking proceedings. ${ }^{55}$ The Court of Appeals was instructed that it had "seriously misread or misapplied"ss the relevant statutory and decisional law. Moreover, the District of Columbia Circuit's demand for adversarial participation to produce an adequate record for judicial review, said the Supreme Court, "fundamentally misconceives the nature of the standard for judicial review of an agency rule." ${ }^{\prime 2 z}$ The mutually reinforcing linkage of the right to participate and the right to judicial review was then severed. The adequacy of the record, said the Court, "turns on whether the agency has followed the

51. Id. at 714 (Brennan \& Marshall, JJ., dissenting).

52. Id. at 721 .

53. New Motor Vehicle Bd. v. Orrin W. Fox Co., 439 U.S. 96, 105 (1978).

54. Id.

55. See supra p. 1136.

56. Vermont Yankee Nuclear Power Corp. v. National Resources Defense Council, 435 U.S. 519, 525 (1978) (Rehnquist, J.).

57. Id. at 547 . 
Rights in the Administrative State

statutory mandate of the Administrative Procedure Act or other relevant statutes."

\section{B. Standing to Sue}

The post- $A D A P S O$ standing cases have not so much abandoned its "zone of interests" analysis as rendered the relevance of that analysis problematic. For the standing cases of the 1970's, while restricting access to the courts, have emphasized "causality" and "nexus" concerns that seem reldted more to the existence of an injury, or to the relationship of the relief requested to the mitigation of the injury alleged, than to the question of what classes of persons may call officials to judicial account. Yet even this is unclear; for the cases certainly insist that two broad categories of persons-citizens and taxpayers-do not by virtue of that status alone have standing to pursue the interests of citizens and taxpayers. Nor may persons having material or other interests conferring standing to litigate certain issues raise grounds of illegality relating to the protection of separable interests not their own.

This line of cases begins with Sierra Club v. Morton. ${ }^{50}$ The Club sought to enjoin certain leases and other proposed developments in aid of the leases on national forest lands in California. Although requested to do so, the Club never alleged that its members had used or ever would use the land in question for pursuits inconsistent with the proposed projects. It urged its standing to sue instead on the basis of its long record of interest in and defense of our national heritage. ${ }^{60}$ The Supreme Court denied the Club standing on the ground that it had failed to allege that it or its members had sustained or would sustain any injury. This failure excluded judicial jurisdiction on Article III grounds. There had been no allegation of a concrete case or controversy.

Because Sierra Club imposed a seemingly innocuous barrier to standing and reconfirmed the Court's disposition to recognize aesthetic, environmental, recreational, and other interests, it was perceived either as insignificant or perhaps as a further confirmation of the "trend" toward liberalized standing. ${ }^{61}$ But, imbedded in the Sierra Club opinion's commitment to the "injury-in-fact" requirement was a complex set of questions concerning what would distinguish an abstract interest in official accountability from a concrete injury giving rise to a right to call officials to account. Moreover, those questions seemed to be of constitutional dimension.

58. Id. (emphasis added).

59. 405 U.S. 727 (1972).

60. Id. at 736 .

61. See Scott, Standing in the Supreme Court-A Functional Analysis, 86 HARV. L. REV. 645, 677 (1973). 
The following Term the Court confronted Linda R.S. v. Richard D., ${ }^{62}$ a suit by an unwed mother complaining of Texas officials' systematic refusal to enforce the state's criminal child support statute. The Court concluded that the plaintiff failed to meet the "injury-in-fact" requirement of Sierra Club:

[W]e hold that ... appellant has failed to allege a sufficient nexus between her injury and the government action. . . . To be sure, appellant no doubt suffered an injury stemming from the failure of her child's father to contribute support payments. But the bare existence of an abstract injury meets only the first half of the standing requirement .... .

Here, appellant has made no showing that her failure to secure support payments results from the nonenforcement, as to her child's father, of [the Texas statute] $\ldots$. . $^{63}$

The Court labelled "speculative" statute would result in future payments to the child.

Two cases decided the next Term look in the same direction. United States v. Richardson ${ }^{85}$ involved a challenge to the section of the Central Intelligence Agency Act that permits the agency to account for its funds solely by a certificate of its Director that they have been properly spent. Richardson filed suit as a federal taxpayer alleging that the Act violated the accounts clause of the Constitution, which provides in part that "a regular Statement and Account of the Receipts and Expenditures of all public Money shall be published from time to time."'8s The Court concluded that Richardson did not have standing because he was not challenging the expenditure of public funds, which might cause him injury as a taxpayer, but only the lack of an accounting. He had thus failed to demonstrate a sufficient nexus between his taxpayer status and the constitutional claim urged. Similarly, in Schlesinger v. Reservists Committee to Stop the War, ${ }^{67}$ the Court found insufficient nexus between the injury to the plaintiffs' interest, as citizens and taxpayers, in the faithful discharge by Congressmen of their legislative duties and the plaintiffs' legal claim that retention by Congressmen of military status as reserve officers violated the appointments clause, which provides that "no Person holding any Office under the United States, shall be a Member of either House

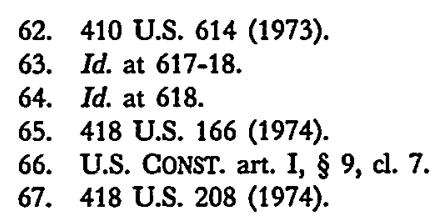


during his Continuance in Office."188

The approach in these cases is puzzling when compared with that of United States v. Students Challenging Regulatory Agency Procedures (SCRAP), ${ }^{\text {e9 }}$ decided in the same Term as Linda R.S. In SCRAP, the plaintiffs, a group of law students, challenged a ruling of the Interstate Commerce Commission (ICG), allowing railroads to exact a surcharge on existing freight rates pending the adoption of selective rate increases. They claimed that the rate surcharge would discourage shipment and use of recyclable goods and thereby contribute to the degradation of the environment in the Washington, D.C., area, an area in which they used the forests, streams, mountains, and other resources for recreation and sightseeing. Over the objections of the railroads and the ICC, the Court found these allegations of injury sufficient to withstand a motion to dismiss:

In interpreting "injury in fact" we made it clear [in Sierra Club] that standing was not confined to those who could show "economic harm," although both Data Processing [ADAPSO] and Barlow [a companion case] had involved that kind of injury. Nor, we said, could the fact that many persons shared the same injury be sufficient reason to disqualify from seeking review of an agency's action any person who had in fact suffered injury. Rather, we explained: "Aesthetic and environmental well-being, like economic well-being, are important ingredients of the quality of life in our society, and the fact that particular environmental interests are shared by the many rather than the few does not make them less deserving of legal protection through the judicial process." . . . Consequently, neither the fact that the appellees here claimed only a harm to their use and enjoyment of the natural resources of the Washington area, nor the fact that all those who use those resources suffered the same harm, deprives them of standing. ${ }^{70}$

These cases are susceptible to several analyses. One is that the Court was rethinking the standing question and had determined, despite the apparently lenient approach in $S C R A P$, that the courts should screen out substantively doubtful claims (as a matter of prudent judicial administration) on the basis of a preliminary objection to standing. A second analysis might suggest that these cases are classic examples of the confusion of "standing" with other aspects of "justiciability." Linda R.S. raised a claim related to "prosecutorial discretion"; Richardson challenged activity in the perennially sensitive area of national security; and Schlesinger involved a collateral attack on the qualifications of members of the legislative

68. U.S. CONST. art. I, § 6, cl. 2.

69. 412 U.S. 669 (1973).

70. Id. at $686-87$ (citation omitted). 
branch. ${ }^{71}$ A third explanation, suggested by Justice Powell's concurrence in Richardson, ${ }^{72}$ was that the Court was becoming generally concerned about the appropriateness under Article III of entertaining lawsuits in which "political" issues predominate. The Court described the Richardson plaintiff as seeking to employ " 'a federal court as a forum in which to air his generalized grievances about the conduct of the government." "73 And the Court in Schlesinger said, "[S]tanding to sue may not be predicated upon an interest of the kind alleged here which is held in common by all members of the public, because of the necessarily abstract nature of the injury all citizens share."74

Justice Stewart, however, read at least Richardson differently. ${ }^{75} \mathrm{He}$ viewed that case as based directly on an interpretation of Article III, and he expressed alarm about what it might foreshadow. Stewart posed, as an example, the question of the constitutionality of Congress' creation (in the Freedom of Information Act) of a right of action by any citizen to force the disclosure of government documents. "If the Court is correct in this case in holding that Richardson lacks standing under Art. III to litigate his claim," Stewart wrote, "it would follow that a person whose request under 5 U.S.C. $\& 552$ has been denied would similarly lack standing under Art. III despite the clear intent of Congress to confer a right of action to compel production of the information."'78

Simon v. Eastern Kentucky Welfare Rights Organization ${ }^{77}$ reinforces at least a portion of the Stewart view - the knotty problem is "injury in fact," the constitutional and non-prudential aspect of standing doctrine. Respondents contested a revenue ruling that altered the Internal Revenue Service's (IRS) interpretation of a "charitable" hospital. Prior IRS interpretations had required that hospitals qualifying for charitable status provide free services to those unable to pay, limited only by the extent of the enterprises' financial ability. The new ruling required that emergencyroom services alone be available to indigents without charge. ${ }^{78}$ Respondents, all of whom or whose members had previously received free treatment at qualifying hospitals, alleged that the relaxed requirements injured them by restricting their ability to receive hospital services on a charitable basis. They claimed that the new definition of "charitable" was not in

71. But cf. Powell v. McCormack, 395 U.S. 486 (1969) (finding standing to challenge congressional review of members' qualifications).

72. United States v. Richardson, 418 U.S. 166, 180 (1974) (Powell, J., concurring).

73. Id. at 173 (majority opinion) (quoting Flast v. Cohen, 392 U.S. 83, 106 (1968)).

74. Schlesinger v. Reservists Comm. to Stop the War, 418 U.S. 208, 220 (1974).

75. United States v. Richardson, 418 U.S. 166, 202 (1974) (Stewart, J., dissenting).

76. Id. at 204-05.

77. 426 U.S. 26 (1976).

78. Id. at 29-32. 
accordance with the congressional intent of section 501 (c)(3) of the Internal Revenue Code and had been issued in violation of the rulemaking requirements of section 553 of the Administrative Procedure Act.

The Court rejected the respondent's standing argument under the "principle" of Linda R.S. The complaint, it held, alleged only that petitioners had "encouraged" hospitals to deny services to indigents by adopting the revenue ruling. The implicit corollary of this allegation was that a

grant of respondents' requested relief, resulting in a requirement that all hospitals serve indigents as a condition to favorable tax treatment, would "discourage" hospitals from denying their services to respondents. But it does not follow from the allegation and its corollary that the denial of access to hospital services in fact results from petitioners' new Ruling, or that a court-ordered return by petitioners to their previous policy would result in these respondents' receiving the hospital services they desire . . . .

It is equally speculative whether the desired exercise of the court's remedial powers in this suit would result in the availability to respondents of such services. So far as the complaint sheds light, it is just as plausible that the hospitals to which respondents may apply for service would elect to forego favorable tax treatment to avoid the undetermined financial drain of an increase in the level of uncompensated services. ${ }^{29}$

$S C R A P$ was distinguished in a footnote on pleading, ${ }^{80}$ and $A D A P S O$ was said to be consistent because there the Comptroller's action "legalized" the harmful activities of competitors. ${ }^{81}$

Justices Brennan and Marshall, concurring specially on "ripeness" grounds, nevertheless agreed with the Simon respondents that the legalization of activity harmful to them was precisely what was happening. ${ }^{82}$ One has to wonder, therefore, why the Linda R.S. riposte had not been thought fitting in ADAPSO. That selling computer services was illegal without the Comptroller's new ruling certainly would not guarantee that the banks would not do it! In frustration, Justices Brennan and Marshall lamented, "We may properly wonder where the Court, armed with its 'fatally speculative pleadings' tool, will strike next."'ss

The Justices are still wondering. The only full-dress rehearsal of the "nexus" issue since that time, Duke Power Go. v. Carolina Environmen-

79. Id. at $42-43$.

80. Id. at $45 \mathrm{n} .25$.

81. Id.

82. Id. at 55-58 (Brennan \& Marshall, JJ., concurring).

83. Id. at 63. 
tal Study Group, Inc., ${ }^{84}$ seems to stand for a preposterous proposition: If a district court believes self-serving testimony in support of otherwise fatally speculative pleadings, then the plaintiffs have standing and the court will reach the merits, even if there is no federal jurisdiction in the first place. Or perhaps Justices Brennan and Marshall came closer to the mark in Simon, when they suggested that the Court's jurisprudence yields instead the simple idea that standing to sue has become discretionary. ${ }^{85}$

\section{Beneficiary Enforcement}

The road from Rosado to the present is in fact three paths that have not, and probably will not, fully converge. The first path leads from Borak and involves actions "implied" from federal statutes. The second proceeds from Rosado and involves section 1983 actions to enforce the obligations of state governments, primarily with respect to federal-state cooperative activities. The third traces damage actions derived directly from the Constitution against federal officials and under section 1983 against state officials. Each path has its own byways and encroaching underbrush. While traversing them we will try to keep the destination in view.

\section{The Path From Borak}

The implied-cause-of-action jurisprudence speaks with the greatest clarity. The "presumption" that persons benefiting from public regulatory legislation can invoke ordinary judicial remedies when injured by others' non-compliance has been reversed.

The reversal began in Cort v. Ash. ${ }^{88}$ This case concerned a shareholder derivative suit to recover corporate moneys expended in a presidential election campaign in violation of 18 U.S.G. $\S 610$, which prohibits corporations from making "a contribution or expenditure in connection with any election at which Presidential and Vice-Presidential electors . . . are to be voted for." ${ }^{\text {"8z }} \mathrm{A}$ unanimous Court set out a four-factor test for determining whether a private remedy is implicit in a statute not expressly providing one. First, is the plaintiff a member of the class for whose special benefit the statute was enacted-that is, does the statute create a federal right in favor of the plaintiff? Second, is there any indication of legislative intent, explicit or implicit, either to create such a remedy or to deny

84. 438 U.S. 59 (1978).

85. See Simon v. Eastern Kentucky Welfare Rights Org., 426 U.S. 26, 54-66 (1976) (Brennan \& Marshall, JJ., concurring).

86. 422 U.S. 66 (1975).

87. 18 U.S.C. $\$ 610$ (repealed 1976). 
one? Third, is it consistent with the underlying purposes of the legislative scheme to imply such a remedy? And finally, is the cause of action one traditionally relegated to state law? ? $^{88}$

The opinion then proceeds to find that all of these considerations point in the same direction. First, Congress was thought to have had only a "secondary concern"89 with protecting shareholders. Its primary concern was protecting the election process. Second, there was no specific congressional intent to "vest in corporate shareholders a federal right to damages." 900 Third, in some astonishing language reminiscent of the standing cases, the Court concluded that the damage remedy was not "necessary to make effective the congressional purpose" because "such a remedy would only permit directors in effect to 'borrow' corporate funds for a time; the later compelled repayment might well not deter the initial violation and would certainly not decrease the impact of the use of such funds upon an election already past."

Having come this far, the conclusion that state law should control was certainly predictable. But again the language is arresting:

Corporations are creatures of state law, and investors commit their funds to corporate directors on the understanding that, except where federal law expressly requires certain responsibilities of directors with respect to stockholders, state law will govern the internal affairs of the corporation. If, for example, state law permits corporations to use corporate funds as contributions in state elections, shareholders are on notice that their funds may be so used and have no recourse under any federal statute. We are necessarily reluctant to imply a federal right to recover funds used in violation of a federal statute where the laws governing the corporation may put a shareholder on notice that there may be no such recovery. ${ }^{92}$

Since Cort, the Court has found an implied cause of action only in quite special circumstances. In one case, for example, the statute stated that transactions in violation of its provisions "shall be void,"93 thus suggesting the private remedy of rescission. In another, the legislative history was, for once, replete with statements that assumed the existence of private actions. ${ }^{94}$ And, in a third, the Court viewed the Congress as acting in the context of uniform acceptance of the existence of an implied right of

88. 422 U.S. at 78.

89. Id. at 81 .

90. Id. at 82 .

91. Id. at 84 .

92. Id. at 84-85 (citation omitted).

93. See Transamerica Mortgage Advisors, Inc. v. Lewis, 444 U.S. 11, 16-17 (1979).

94. See Cannon v. University of Chicago, 441 U.S. 677, 689-709 (1979). 
action. ${ }^{95}$

In recent cases, several members of the Court have striven to make clear that the only real question is legislative intent, and Justice Powell has opined that any "implication" of rights not specifically intended to be conferred by the Congress would involve an unconstitutional aggrandizement of judicial power. ${ }^{98}$ Indeed, so fixated on the statute has the Court become that it has refused to recognize a right of contribution between joint tortfeasors with respect to an express statutory cause of action because such a right was not in the statute. ${ }^{97}$ And in Milwaukee v. Illinois, ${ }^{98}$ in 1981, reversing its position in Illinois v. Milwaukee, ${ }^{99}$ decided in 1972, the Court ruled that federal water pollution control statutes and the administrative regime they envisage have wholly supplanted the federal common law in interstate pollution suits.

\section{The Path from Rosado}

Rosado-style enforcement of state obligations has met a more complicated fate. Early restrictions on the state instrumentalities that might be sued as "persons" pursuant to section 1983 have evaporated, ${ }^{100}$ and state immunity under the Eleventh Amendment has remained restricted to the state's immediate officials. ${ }^{101}$ Moreover, the Court passed by the invitation to restrict section 1983 actions to enforce statutory rights to those based on "civil rights" legislation ${ }^{102}$ - a restriction found in the federal courts jurisdictional statute, originally passed to facilitate the section 1983 cause of action. ${ }^{103}$

Expansive interpretation of the remedial statute, section 1983, however, has been accompanied by a cautious approach to the recognition of rights. The Pennhurst case, ${ }^{104}$ for example, holds that sections of a federal grant statute that were legislatively characterized as a "bill of rights" for the developmentally disabled contain merely precatory language, not creating any enforceable rights. Pennhurst may only signal increased solicitude for fiscally strained state grantees when pursued by the putative beneficiaries of joint federal-state spending programs that are meagerly funded at the federal level. Alternatively, Pennhurst may be the beginning of a unifica-

95. Merrill Lynch, Pierce, Fenner \& Smith, Inc. v. Curran, 456 U.S. 353 (1982).

96. See Cannon v. University of Chicago, 441 U.S. 677, 742-44 (1979) (Powell, J., dissenting).

97. See Northwest Airlines, Inc. v. Transportation Workers Union, 451 U.S. 77 (1981).

98. 451 U.S. 304 (1981).

99. 406 U.S. 91 (1972).

100. See Monell v. Department of Social Servs., 436 U.S. 658 (1978).

101. See Lake Country Estates, Inc. v. Tahoe Regional Planning Agency, 440 U.S. 391 (1979).

102. See Maine v. Thiboutot, 448 U.S. 1 (1980).

103. 28 U.S.C. $\$ 1343$ (1982).

104. Pennhurst State School \& Hosp. v. Halderman, 451 U.S. 1 (1981). 
tion of Rosado-style section 1983 actions with the implied right of action cases and standing doctrine.

Indeed, the impetus to unify these divergent strains of "rights" jurisprudence may prove irresistible. When the federal government regulates $X$ 's private conduct for the benefit of $Y, Y$ now has no implied action against $X$ absent evidence of legislative intent approximating an explicit congressional conferral of a cause of action. And under contemporary standing doctrine, the enforcement failures of the agency charged with regulating $X$ 's behavior are also free from demands for judicial accounting by $Y$ unless the agency action requested would directly confer the benefit $Y$ seeks. In general, the relationship of agencies and their regulated parties may not be controlled by assertion of beneficiary rights against either, absent direct statutory conferral of such rights. Why should the situation change when the regulated party happens to be a public entity?

The mere existence of section 1983 may not prove a sufficient answer to that question. The National Sea Clammers ${ }^{105}$ case says so explicitly. There, commercial fishing interests sought damages from various state sewerage authorities that had despoiled their fishing grounds in violation of federal water pollution statutes. The action was brought on an implied right of action theory, but the Supreme Court recognized the potential applicability of section 1983 . Nevertheless, the action was rejected. In the Court's opinion, the federal water pollution statutes, by establishing a comprehensive scheme of regulation of private and public water pollution (the latter predominately by means of sewerage treatment grant conditions), had evinced a legislative intent to exclude private enforcement actions. Because the water pollution statutes post-date section 1983, the later expression of intent, of course, prevails. A similar result was reached in California v. Sierra Club ${ }^{108}$ without discussion of section 1983.

It is, of course, much too early to predict confidently where National Sea Clammers and California v. Sierra Club might lead. But movement toward precisely the primary administrative jurisdiction position rejected in Rosado is hardly unthinkable. The occasional solicitude of the Court for the "common law" in "implicit repeal" cases ${ }^{107}$ does not necessarily attach to section 1983. And such a position would be consistent with the emerging principle that parties have that set, and only that explicit set, of rights and remedies given them by statutes.

105. Middlesex County Sewerage Auth. v. National Sea Glammers Ass'n, 453 U.S. 1 (1981).

106. 451 U.S. 287 (1981).

107. See Nader v. Allegheny Airlines, Inc., 426 U.S. 290 (1976). 


\section{The "Constitutional-Tort" Path}

Only in the area of remedies for violations of constitutional rights have events unfolded as might have been predicted around 1970. The Bivens ${ }^{108}$ action under the Fourth Amendment has been joined by actions under other provisions, including importantly the due process clauses of the Fifth ${ }^{109}$ and Fourteenth Amendments. ${ }^{110}$ Sovereign immunity remains a barrier to recovery, but official immunity has been relaxed for actions against both federal and state and local officials. ${ }^{111}$ The quasi-tort principles surrounding these actions have been determined to be federal common law, ${ }^{112}$ governable, perhaps, but not yet governed, by federal statute. That common law is not consistently generous, and some see developments taking a restrictive turn. ${ }^{113}$ Yet, administrative hearing rights aside, independent judicial construction of constitutional rights and remedies seems relatively secure until the Congress becomes more active in implementing those rights. ${ }^{114}$

\section{What Happened?}

The qualification in the last sentence is, of course, one key to what has happened. A restrained judicial technique in an activist state will ratify the statutory and administrative structures that the activist state generates. If those structures are based on principles of collective need and centri:administration, then the restrained judicial conception of law will similarly reflect those principles. One would expect such a development in a unitary legal system. Where ideas of federal-state jurisdiction further restrict the development of federal common law and thereby deprecate judicial creativity, ${ }^{115}$ the result is a dramatic emphasis on legislative and administrative activity as the generative force in the federal legal system. The operative conception of law becomes, institutionally, the image of the legislative-administrative state, and, substantively, the principle of the pursuit of the general welfare. Individual rights and individual legal identity are then dependent upon either explicit recognition in a legislativeadministrative edict or upon derivation from a collective expression defined by joint legislative-administrative activity.

108. Bivens v. Six Unknown Named Agents of the Fed. Bureau of Narcotics, 403 U.S. 388 (1971).

109. Davis v. Passman, 442 U.S. 228 (1979).

110. Youngberg v. Romeo, 457 U.S. 307 (1982).

111. See, e.g., Harlow v. Fitzgerald, 457 U.S. 800 (1982); Butz v. Economou, 438 U.S. 478 (1978).

112. Carey v. Piphus, 435 U.S. 247, 257-59 (1978).

113. Whitman, Constitutional Torts, 79 MiCH. L. REV. 5 (1980).

114. See P. SCHUCK, SUING GOVERNMENT: CITIZEN REMEDIES FOR OFFICIAL WRONGS (1983).

115. See Cannon v. University of Chicago, 441 U.S. 677, 730 (1979) (Powell, J., dissenting). 
Indeed, the cases that make up the volume 397 "pro-rights" collection do not really deny this perspective. The prior discussion stresses aspects of, and language in, the cases that are undeniably there, but gives only a partial picture of the context and reasoning involved. In Goldberg, for example, the recognition of the recipient's right to a pre-termination hearing is premised in part on the program's need for accurate withdrawal decisions: "The same governmental interests that counsel the provision of welfare, counsel as well its uninterrupted provision to those eligible to receive it; pre-termination evidentiary hearings are indispensable to that end."118 The recipient has a right because the government needs for him to have one. Here lie the seeds, if not the sprouts, of the general welfare calculation that will blossom in Mathews v. Eldridge. ${ }^{117}$ There, of course, it is revealed-to extend the metaphor-as a parasitic flower. The coalescence of individual and social interests seems to devour the individual rights ideals of Goldberg and metabolize them into a diaphanous tissue of social cost accounting. ${ }^{118}$

Borak and Rosado will support a similar analysis. Cort v. Ash is not wholly disingenuous when it argues that the Borak Court relied on the necessity of private enforcement to accomplish Congress' aims--a position strongly supported in the litigation by the Securities and Exchange Commission. ${ }^{110}$ In Rosado the Court opines:

That these formal doctrines of administrative law do not preclude federal jurisdiction does not mean, however, that a federal court must deprive itself of the benefit of the expertise of the federal agency that is primarily concerned with these problems. Whenever possible the district courts should obtain the views of HEW in those cases where it has not set forth its views, either in a regulation or published opinion, or in cases where there is real doubt as to how the Department's standards apply to the particular state regulation or program.

The District Court, in this instance, made considerable effort to learn the views of HEW. The possibility of HEW's participation, either as a party or an amicus, was explored in the District Court and the Department determined to remain aloof. We cannot in these circumstances fault the District Court for proceeding to try the case. ${ }^{120}$

116. Goldberg v. Kelly, 397 U.S. 254, 265 (1970).

117. 424 U.S. 319 (1976).

118. See Mashaw, Administrative Due Process as Socjal-Cost Accounting, 9 HOFSTRA L. REv. 1423 (1981); Mashaw, The Supreme Court's Due Process Calculus for Administrative Adjudication in Mathews v. Eldridge: Three Factors in Search of a Theory of Value, 44 U. CHI. L. REV. 28 (1976).

119. Cort v. Ash, 422 U.S. 66, 79 n.11 (1975).

120. Rosado v. Wyman, 397 U.S. 397, 406-07 (1970) (footnote omitted). 
And it is but a short step from saying that plaintiffs have a justiciable right only where the agency welcomes private assistance, or is indifferent to it, to saying that the agency should not have to police constantly the boundaries of its enforcement jurisdiction by intervening in private lawsuits.

Finally, ADAPSO has its own special limitations. ${ }^{121}$ For while the $A D A P S O$ holding permits pleadings to survive a motion to dismiss where the interest asserted is "arguably within the zone of interests protected or regulated," it reserves for the merits the question whether the plaintiff has in fact been given an enforceable right. The plaintiff may demonstrate injury in fact and official illegality, yet lose because no special duty to behave legally was owed to him. Whether it was owed is, of course, a question of whether the legislature intended to confer the right. Upon moving from the pleading to the summary judgment stage, the pre$A D A P S O$ standing idea of "legal wrong," statutorily based, re-emerges as clearly as does the limiting effect of "injury in fact" in the jurisprudence from Linda R.S. to Simon.

The "individual rights" cases are thus themselves Janus-faced. They assert individual rights without abandoning the need to locate those rights in state purposes. They are the hybrid creations of an activist court attempting to bridge the gap between two quite distinct conceptions of the legal order. But hybrids are not necessarily fecund. Indeed, save in exceptional circumstances, we should expect that they would either disappear or be an insignificant addition to an environment dominated by the species which spawned them. This, I want to argue, has been the fate of the volume 397 cases. But to do so I must first identify more clearly what the dominant species are and what characteristics the volume 397 hybrids inherited from each. We can then see developments after 1970 as a relatively coherent extension of the parents' traits, while leaving the hybrids a specific niche defined by the interaction of their special genetic endowments with the general politico-legal environment.

\section{The Models of Statist and Individualist Legal Rights Refined}

The rights to participation, accounting, and third-party-beneficiary enforcement have not been very well specified. What, in fact, do I mean when I say that someone has one of these rights? The answer is straightforward and traditional: I mean that they have a cause of action, a claim recognizable and enforceable in a court. The question in all of the cases and contexts previously discussed is whether certain rights, of particular 
importance in an administrative state, will be found to exist.

I want to suggest in this section that this "finding" of rights goes on within a legal culture that has certain rules of recognition, that is, certain ways of seeing claims as justiciable and as, therefore, within the domain of judicially enforceable rights. Indeed, I want to argue that there are two quite distinct ways of "seeing"122 rights and that only those that can be seen in a particular way will be thought justiciable. These ways of seeing are, thus, also ways of allocating power among legal institutions. The creation, elaboration, and enforcement of rights that can be seen in the "individualist" conception are allocated to courts; those that are observable only from the "statist" perspective are allocated to legislative and administrative institutions with courts playing only an instrumental enforcement role in realizing legislative and administrative purposes.

How then shall we describe these ways of seeing that make up the American legal culture? Consider a stylized formulation of a legal right: " $A$ owes a duty to $B$ to do (or to refrain from) $X$ because of $Y$." If we can provide a sketch of how these $A s$ and $B s$ and $X s$ and $Y \mathrm{~s}$ are to be elaborated in the respective individualist and statist formulations, then we are on the way toward a description of the legal culture and how it typically allocates power over rights. We can then move somewhat beyond the elements of rights $(A, B, X$, and $Y)$ to develop some additional characteristics of statist and individualist legal thinking that touch on questions of the sources of legal authority and the orientation of each perceptual model to the general social and political order. ${ }^{123}$ Derivation of these elements and characteristics and their association into more detailed models of individualist and statist legal rights is the business of the next two sections.

\section{A. The Elements of Rights}

Consider first the characteristics of $A$ and $B$, the subjects and objects of rights in the formal rights statement. In the individualist model (which I shall refer to as "IM") both are individuals or collectivities to whom an individual legal personality has been given, like Joe Smith, Sally Brown, Local 125 of the Pipefitters and Boilermakers Union, IBM, the government of Argentina. The statist model (which I shall refer to as "SM"), on the other hand, imagines $A$ and $B$ (or at least one of them) as groups-labor, blacks, women, society, environmentalists, manufacturers, the poor, the rich-that may or may not have a private legal personality. The SM has no difficulty seeing "interest groups"; the IM can see them

122. This metaphor is that of J. VINING, supra note 24 , at 16 .

123. See Damaska, Structures of Authority and Comparative Criminal Procedure, 84 YALE L.J. 480 (1975); M. DAMASKA, LAW, AUTHORITY AND THE STATE: A COMPARATIVE APPROACH TO THE LEGAL PROCESS (forthcoming). 
only if they take a certain limited number of legal forms.

Second the "duty" relationship between $A$ and $B$ is general or reciprocal in the IM. The subjects and objects of rights can be switched with no loss of meaning. The content of the duty is an action or restraint-delivery, payment, caution, or the like-that is available to all the legal actors represented by the $A$ and $B$ placeholders. The IM may sometimes speak of general categories-creditors' rights or debtors' obligations, for example-but these legal characterizations are transaction-specific; they flow from the contingency of holding a particular position within the structure of some particular claim of legal right. The same is not true of the SM sphere. There identities are fixed by facts unrelated to particular legal claims and entail non-reciprocal rights and duties. Labor, for example, does not owe management a safe place to work or a duty not to interfere in efforts to organize collectively. Blacks do not owe whites the same duty of non-discrimination that whites owe blacks. To switch the parties in SM talk is to change the duty owed.

This distinction between the general or special content of $X$, the duty owed, begins to tell us something about $Y$, the reason that lies behind the right. Since the parties cannot be switched in the statist model, the rights and the condition of being the subject or object of rights are attached in some way to status. $A$ 's owing $B$ arises out of who $\mathrm{A}$ and $\mathrm{B}$ are. In the IM picture, the duty arises out of communications or physical interactions with respect to which the group status of the actors is irrelevant. Rights flow from events, not descriptions of legal personality. Particular actions are the attributes of parties that are relevant to an IM allocation of benefits and burdens; general status plays that role from the SM perspective.

But these two observations about $X$ and $Y$, the content of rights and reasons for their existence, only begin to tell us how claims are articulated. We need a further elaboration of the linkages ${ }^{124}$ between $A$ and $B$ to make rights perceptible within the individualist and statist models. In particular, we need to know when actions and statuses are relevant and how that conception of relevance is justified. What are the occasions for rights-enforcement and what principles make those occasions morally justifiable?

In the IM world, action becomes relevant when there is loss- $A$ hits $B$ or takes her car without paying the price. Examples of loss involving administrative behavior include $A$ revoking $B$ 's license or invading his privacy by searching his premises. SM spectacles, by contrast, have greater peripheral and probabilistic vision. They see risks rather than losses.

124. See Calabresi, Concerning Cause and the Law of Torts: An Essay for Harry Kalven, Jr., 43 U. CHI. L. REv. 69 (1975) (developing variations on idea of "causation" as essential linkage). 
Claims may be cognizable on the ground that $A$ creates conditions that increase the risk that $B$ will be hit, will fail to get what it imagined it was getting from its bargain, or will be systematically disadvantaged in a market economy. Examples of SM claims involving the kinds of rights we have been discussing would include $A$ failing to keep $Z$ within the terms of its discharge permit, thereby increasing $B$ 's health risks; $A$ conscripting $B$ into the army, thereby impairing $B$ 's future earning prospects and increasing $B$ 's risk of disability; and $A$ freely enforcing contracts in private markets, thereby creating the risk that $B$ 's particular human capital will be given a low value.

Neither all losses nor all risks, however, occasion rights creation or enforcement. In each model, there must be a moral rationale for recognizing or selecting particular loss or risk linkages as legally relevant. The internal moral principle that informs the IM universe is corrective justice. ${ }^{125}$ When $A$ harms $B$ by upsetting his expectations that his personal property will be secure against invasion, he must repair the damage, provided he caused the damage by some action or inaction that was (under the circumstances) unreasonable or he profited unjustly by $A$ 's loss. The IM structure of moral justification can be captured in a few general legal principles concerning reasonable expectations, prudent conduct, and unjust enrichment.

Different moral principles inform rights in the statist conception. In general terms, they are the pursuit of the general welfare and the maintenance of a minimally just overall distribution of resources. From this perspective, $A$ may be required to act so that $B$ 's risks of loss are reduced provided some plausible story can be told about general welfare being enhanced thereby. And $A$ might be required to pay taxes to support $B$ on the basis of either general welfare or just distribution arguments. Indeed, general welfare and just distribution stories may be as various as the interests and distributional values that any group within the society might be said to hold. General welfare and just distribution "principles" thus inhabit a kaleidoscope of governmental policies and programs, each with its own complex rationale.

\section{B. Some Additional Characteristics}

We have so far two clusters of characteristics that describe the basic elements of rights formulations in the individualist and statist models. Those characteristics are defined by distinct conceptions of legal personal-

125. See Coleman, Corrective Justice and Wrongful Gain, 11 J. LEGAL STUD. 421 (1982); Coleman, Moral Theories of Torts: Their Scope and Limits (pts. 1 \& 2), 1 LAW \& PHL. 371 (1982), 2 LAW \& PHIL. 5 (1983). 
ity (individual-group), of the scope of duties (general-specific), of the occasions for legal intervention (loss-risk), of the attributes relevant to allocating benefits and burdens (acts-statuses), and of the moral underpinnings for legal claims (corrective justice-general welfare or distributional fairness). These characteristics of IM and SM rights together suggest a further series of conceptions concerning rights-creation, the authoritative sources of law, the structure of legal authority, and, ultimately, the nature of social processes and the role of the state. These ideas again may be briefly sketched.

The source of IM ideas about reasonable conduct, just expectations, and the like, which constitute the operative notion of corrective justice, is the specific culture within which the events giving rise to claims of right occur. Rights are recognized as emerging from the traditions and practices that give pattern and meaning to the culture itself. Law thus has its source in practice. SM conceptions of policy based on distributional fairness or the general welfare arise, by contrast, from self-conscious and purposive collective action. Law is constructed through rational assessment of ends and means or through some authoritative process of preference aggregation. ${ }^{126}$

The institutions through which law is created and applied are thus quite different in the two models. Judgments resolving individualized disputes arising out of specific contexts and concerning the requirements of traditional notions of corrective justice require adjudicatory mechanisms anchored in the communities of the disputants. The construction and operation of legal regimes designed to increase distributional fairness or the general welfare by adjusting the relationship of groups require both a general social perspective and a managerial competence. IM presumes the processes of tribunals; SM the operations of legislative and administrative organs. ${ }^{127}$

The structure of legal authority in an individualist regime is characterized by coordinate power and by lay officials. The tribunal as cultural arbiter has a localized expertise through its attachment to the community. Centralized state direction or norm creation would be dysfunctional. Jurisdiction is therefore territorial and coordinate. But the expertise referred to does not result from professional training or specialized experience. It is rather the expertise of the cultural insider, an expertise easily available to lay judges and juries. Given the random and episodic nature of the occa-

126. Cf. B. ACKERMAN, PRIVATE PROPERTY AND THE CONSTITUTION (1977) (describing two approaches to lawmaking-"ordinary observing" and "scientific policymaking"-in quite similar terms).

127. Chayes and Fiss have made particularly noteworthy efforts to reinterpret the paradigm in the American public law context. See Chayes, The Role of the Judge in Public Law Litigation, 89 HARV. L. REV. 1281 (1976); Fiss, The Supreme Court, 1978 Term-Foreword: The Forms of Justice, 93 HARV. L. REV. 1 (1979). 
sions for the exercise of legal authority, dispute resolution might even be carried on by wholly ad hoc tribunals.

By contrast, the statist model sees the exercise of legal authority as the implementation of a complex plan. Moreover, given that legal means may have a non-obvious causal relationship to social goals, there is a need for technical expertise in the design of policies and for centralized direction and continuous supervision in carrying them out. The structure of legal authority in SM regimes, therefore, tends to be both centralized and professional.

These structures of authority seem further to involve certain presuppositions about social processes and the role of the state. The individualist model presumes a social order that is autonomous and relatively stable. The law derives its norms from the culture and applies authority (or vindicates rights) in order to reestablish the social equilibrium that has been disturbed. Moreover, this intervention to reconstruct the status quo ante exhausts the state's role in shaping the social world. The statist vision, by contrast, is of a social process both dynamic and malleable. Rational collective action defines social goals and embodies them in law. Legal authority is then wielded to shape the social future in accordance with those goals. The state thus has a potentially inexhaustible role in the ongoing process of social realization.

Table 1 collects these pairs of conceptions into a set of selective characteristics of the individualist and statist models of law. I do not want to argue that these models remain pure in practice or that there is any logical necessity for the arrangement. Individual legal personality and a perception of risk, for example, can be combined as can state activism and coordinate authority. ${ }^{128} \mathrm{My}$ point is only that these characteristics tend to be associated in these ways in the American legal system and that we can trace analytic linkages within the two models that, while falling short of logical entailment, suggest a certain harmonious interconnection of the characteristics.

The advantage of viewing the recognition of rights in terms of these polar models is that they emphasize the conceptually problematic position of rights in the American administrative state. We are here dealing with rights asserted in litigation, an IM form, but relating to SM structures. This juxtaposition creates a struggle between the two models for primacy with respect to the conception of rights that will be employed, a struggle that may range across at least the characteristics of rights that we have sketched and that may be resolved in any number of ways. Note, however, that to the extent that the statist model becomes the dominant image of

128. See Damaska, supra note 123. 
federal administrative law, it will pose grave problems for judicial adjudication. Numerous characteristics of the individualist model are incorporated in conventional notions of justiciability. To maintain a significant judicial role in this public legal order, the courts will either have to transform themselves into institutions more closely resembling legislatures and administrative agencies or they will have to "individualize" public law assertions of interests and responsibilities by translating them into justiciable rights and duties fitting more or less within the individualist model. ${ }^{\mathbf{1 2 9}}$

\begin{tabular}{|c|c|c|}
\hline $\begin{array}{l}\begin{array}{l}\text { Dimensions } \\
\text { of Rights }\end{array} \\
\begin{array}{r}\text { Rights } \\
\text { Paradigm }\end{array}\end{array}$ & $\begin{array}{l}\text { Individualist } \\
\text { (Private Law) }\end{array}$ & $\begin{array}{l}\text { Statist } \\
\text { (Public Law) }\end{array}$ \\
\hline $\begin{array}{l}\text { Recognizable } \\
\text { Claimants/Debtors (A\&B) }\end{array}$ & neutral placeholders & $\begin{array}{l}\text { groups, often with } \\
\text { distinctive interests } \\
\text { (or general public) }\end{array}$ \\
\hline $\begin{array}{l}\text { Characteristic Duty (x) } \\
\text { Formulations }\end{array}$ & $\begin{array}{l}\text { general/ } \\
\text { reciprocal }\end{array}$ & $\begin{array}{l}\text { special/ } \\
\text { unilateral }\end{array}$ \\
\hline $\begin{array}{l}\text { Standard Occasions } \\
\text { for Legal Intervention }\end{array}$ & & risk \\
\hline $\begin{array}{l}\text { Attributes Relevant to } \\
\text { Allocating Benefits/Burdens } \\
\text { Principle of Justice }\end{array}$ & $\begin{array}{l}\text { actions } \\
\text { corrective }\end{array}$ & $\begin{array}{l}\text { statuses } \\
\text { general welfare } \\
\text { distributional equity }\end{array}$ \\
\hline \multicolumn{3}{|l|}{ Additional Characteristics } \\
\hline Sources of Rights & evolving custom & $\begin{array}{l}\text { means-ends rationality } \\
\text { (collective choice) }\end{array}$ \\
\hline $\begin{array}{l}\text { Orientation to } \\
\text { Social Order }\end{array}$ & derivative & directive \\
\hline $\begin{array}{l}\text { Characteristic } \\
\text { Authority Structure }\end{array}$ & $\begin{array}{l}\text { decentralized, lay } \\
\text { tribunal }\end{array}$ & $\begin{array}{l}\text { centralized, expert } \\
\text { administrative agency }\end{array}$ \\
\hline
\end{tabular}

Table 1

VI. Mediating the Claims of the Individualist and Statist Models: From Laissez Faire Through the Legitimation of the New Deal

But these are in some sense polar strategies for coping with the recognition that a new public legal order, call it the administrative state, has

129. See D. Horowitz, The CouRTS AND Social Policy (1977); Chayes, supra note 127; Fiss, supra note 127. 
arisen. For most of the period in which we could be said to have had a federal administrative law, the courts have instead been content to function, in somewhat different capacities, on both sides of an uneasy border between the individualist and statist conceptions of public law. Indeed, a brief sketch of how the federal legal order evolved into semi-autonomous branches and how doctrines concerning standing, hearing rights, and implied actions shifted to accommodate that evolution will set the stage for reconsidering the intellectual significance of the volume 397 cases.

\section{A. The General Legal Culture}

If we took the beginning of the twentieth century as a somewhat arbitrary starting point, the American legal universe would obviously look quite different than it does today. Law would appear to be primarily private law, the common law of tort, property, and contract. Public law would consist principally of crimes and taxes. ${ }^{130}$ Although experiments with social and economic legislation were increasing, ${ }^{131}$ the common law was sufficiently unified that the federal courts could develop and apply $\mathrm{it}^{\mathbf{1 3 2}}$ without noticing the impairment of state power that was to provoke Erie R.R. v. Tompkins. ${ }^{133}$ Much of the earlier and distinctive state regulatory legislation-the raw materials for multiple statist legal systems-had been swept away by a combination of Jacksonian populism and free enterprise capitalism. ${ }^{134}$ The central image of law was thus the common law, judicially made in suits between private parties concerning their rights. This was positive law that emerged from the bottom up in a decentralized process of dispute resolution. A rough approximation of the IM conception of rights prevailed.

This is the legal world of International News Service v. Associated Press, ${ }^{136}$ a world in which the majority of the Court felt it could isolate and adjudicate private rights to "the news" without considering the public interest in its dissemination. The defendant INS's principal argument, that it, as a part of the public, could use stories that AP had placed in the public domain, was indeed described by the Court as the "fault in [its] reasoning."' ${ }^{\text {"36 }}$ Equity was concerned instead with corrective justice and, as between AP and INS, the Court could easily recognize a limited property right in order to prevent unjust enrichment. In the Court's words, "[A]

130. See L. FRIEDMAN, A HISTORY OF AMERICAN LAW 494-524, 567-95 (1973).

131. See J. HuRST, THE GROWTH OF AMERICAN LAW: THE LAW Makers 395-97, 406-11 (1950).

132. See Swift v. Tyson, 41 U.S. (16 Pet.) 1 (1842).

133. 304 U.S. 64 (1938).

134. See L. White, THE Jacksonians 457-58 (1954).

135. 248 U.S. 215 (1918).

136. Id. at 239 . 
competitor who is misappropriating [news] for the purpose of disposing of it to his own profit and to the disadvantage of complainant cannot be heard to say that it is too fugitive or evanescent to be regarded as property."137 The Court, therefore, let stand an injunction against INS use of AP news "until its commercial value as news to the complainant had passed away."138 The individualist paradigm-discrete events, concrete loss, placeholder parties and the morality of rectification-shapes the analysis.

Yet a new day was already dawning. For Justice Brandeis in dissent, the simple injustice identified by the Court was clear enough. But Brandeis could not forget that the world had become complex:

The unwritten law possesses capacity for growth . . . by invoking analogies or by expanding a rule or principle. This process has been in the main wisely applied and should not be discontinued. Where the problem is relatively simple, as it is apt to be when private interests only are involved, it generally proves adequate. But with the increasing complexity of society, the public interest tends to become omnipresent; and the problems presented by new demands for justice cease to be simple. Then the creation or recognition by courts of a new private right may work serious injury to the general public, unless the boundaries of the right are definitely established and wisely guarded. In order to reconcile the new private right with the public interest, it may be necessary to prescribe limitations and rules for its enjoyment; and also to provide administrative machinery for enforcing the rules. It is largely for this reason that, in the effort to meet the many new demands for justice incident to a rapidly changing civilization, resort to legislation has latterly been had with increasing frequency. ${ }^{139}$

Indeed, as Brandeis proceeds he begins to sketch the statist model. $\mathrm{He}$ is concerned both about the social and political conditions that influence the access that different organizations have to news sources and about the possible need to impose a responsibility for public dissemination should a property right in "collected" news be recognized. He was further concerned that remedies be tailored to protect the public interest and he doubted that judicial relief of any sort could be as efficacious as continuous monitoring and adjustment by "administrative machinery." From Brandeis' perspective, assigning private rights to particular interests might well help protect the public interest, but then again it might not. The general question was not inter-party corrective justice. It was instead how

137. Id. at 240 .

138. Id. at 245-46.

139. Id. at 262-63 (Brandeis, J., dissenting). 
to devise a comprehensive scheme that would promote the general welfare by adjusting the various interests affected.

It is, of course, just this view of the world that emerges triumphant from the politics of the 1920's and 1930's. But the legal acceptance of the statist model was neither easy nor complete. The story of the Old Court and the New Deal is too oft-told a tale to rehearse here-even in a conference with the title of this one. But we might tarry just long enough to put a central feature of that struggle-the labor contract-into our present vernacular. For a time, the Court simply could not conceive of workers and management, of a legislatively shaped employment status, and of rights flowing out of conditions. It saw instead individuals making contracts whose terms were subject to their wills. Yet, in the end, the statutory barrage from progressive state legislatures and New Deal Congresses re-educated the judiciary. The Court ultimately recognized not only the legitimacy of legislative tinkering, but also the conceptual revolution that administrative law entailed.

The leading cases of the immediate post-New Deal period reflect this understanding. In the famous Hearst case, ${ }^{140}$ for example, the Hearst Newspapers attempted to avoid application of the National Labor Relations Act (NLRA) to their "newsboys" by arguing that they were not employees but independent contractors. The company claimed, moreover, that there was no evidence upon which the National Labor Relations Board could find employee status. The Supreme Court first rejected the notion that the word "employee" in the NLRA retained its common law meaning. It then went on to describe the role of the Court and the Board in developing the meaning of "employee":

It is not necessary to this case to make a completely definitive limitation around the term "employee." That task has been assigned primarily to the agency created by Congress to administer the Act. Determination of "where all the conditions of the relation require protection" involves inquiries for the Board charged with this duty. Everyday experience in the administration of the statute gives it familiarity with the circumstances and backgrounds of employment relationships in various industries, with the abilities and needs of the workers for self-organization and collective action, and with the adaptability of collective bargaining for the peaceful settlement of their disputes with their employers. The experience thus acquired must be brought frequently to bear on the question who is an employee under the Act. Resolving that question, like determining

140. NLRB v. Hearst Publications, Inc., 322 U.S. 111 (1944). 
whether unfair labor practices have been committed, "belongs to the usual administrative routine" of the Board. ${ }^{141}$

\section{B. The Rights in Question}

Comparing the standing, right to hearing, and implied action jurisprudence of the first three decades of this century to that of the late 1930's and 1940's reveals a similar development. At first, the individualist model shapes the legal imagination. Then the statist model gains recognition and is almost simultaneously viewed as autonomous, as separate both conceptually and institutionally from the individualist conception of rights. Two parallel systems then exist with the Court as their institutional nexus. The problem for the Court, ultimately, is to mediate the claims of the two systems for the same judicial territory. And here the development of the doctrines that have held our attention may diverge.

\section{Standing}

The standing cases illustrate these general propositions fairly happily. Around 1920, the Court clearly recognized only an IM form of standing. A party could sue a government official only if directly harmed by wrongful official action. The "wrong" might be established either by the private common law or by the specific terms of a statute. The action was essentially a private lawsuit in which the official would plead her authority to act as a defense. ${ }^{142}$ To have standing was to have what was conventionally understood as a private cause of action.

By at least 1940, a statist version of standing had emerged. A party had standing if the Congress had conferred it in the public interest, that is, had made persons of the plaintiffs' class "private attorneys general" to police the actions of federal officials. ${ }^{143}$ These new standing rights emerged pursuant to legislative prescriptions specially providing judicial review to any person "adversely affected or aggrieved." "144 The federal Administrative Procedure Act (APA) of 1946, ${ }^{145}$ which "restated" more than it reshaped the law, ratified both the individualist and the statist conceptual bases for recognizing party standing to seek judicial review of agency action.

141. Id. at 130 .

142. See, e.g., Perkins v. Lukens Steel Co., 310 U.S. 113 (1940); Alexander Sprunt \& Son, Inc. v. United States, 281 U.S. 249 (1930); Edward Hines Yellow Pine Trustees v. United States, 263 U.S. 143 (1923).

143. See, e.g., FCC v. Sanders Bros. Radio Station, 309 U.S. 470 (1940); Associated Indus. v. Ickes, 134 F.2d 694 (2d Cir.), vacated as moot, 320 U.S. 707 (1943).

144. E.g., Federal Communications Act of 1934, 47 U.S.C. $\$ 402(b)(6)(1976)$.

145. Pub. L. No. 79-404, $\S 10(a), 60$ Stat. 241 (1946) (current version at 5 U.S.C. $\S \S 500-576$, 701-706 (1982)) 


\section{The Right to a Hearing}

The right-to-a-hearing story is rather more complicated, but again two types of rights emerge. One is the common law image of a judicial trial. It has been elaborated as a requirement of constitutional due process, but draws on common law sources of procedural fairness that antedate both our due process clauses. The other is a right, often informed by the IM ideal, but dependent upon specific legislation for its existence and, after 1946, either upon a specific statute or the APA for its content.

The complication in the story is, of course, that the Court always recognized that a judicial or "quasi-judicial" trial was not the only constitutional means of exercising governmental power. Yet, by 1920, the leading cases affirmed that a complaining party was entitled to present both oral argument and testimonial proofs before having any individual right (meaning "liberty" or "property" as conventionally understood) determined. ${ }^{146}$ Such a requirement is both profoundly anti-bureaucratic and, in the right hands, wonderfully obstructionist. This latter point was hardly lost on the opponents of state social legislation. Indeed, procedural due process was employed ${ }^{\mathbf{1 4 7}}$ to invalidate state regulation a decade prior to Lochner's famous substantive version. ${ }^{148}$ The IM paradigm, as a normative constitutional conception, included the notion that private property claims had to be considered by the methods of private law process.

Yet as early as 1915, the Court had also admitted that administrators could employ legislative-style processes to deal with issues of general, rather than individual, interest. ${ }^{149}$ As many statutes addressing general questions of public or group interest impressed the statist model of rights on the legal imagination, more and more administrative functions under those statutes came to be viewed as essentially "legislative." The processes to be used in these new SM arenas were then creatures of the statutory regimes themselves. The question of whether and what kind of hearings were required became a question to be addressed by purposive statutory construction rather than by reflecting on the customary procedures of the private law. ${ }^{180}$

There was still, of course, the awkward problem of deciding whether the plaintiff was asserting a common law right subject to protection through judicial process or a legislative interest capable of adjustment by whatever process promoted the general welfare. And the awkward

146. See Londoner v. Denver, 210 U.S. 373 (1908).

147. See Chicago, Mil. \& St. P. Ry. v. Minnesota, 134 U.S. 418 (1890).

148. Lochner v. New York, 198 U.S. 45 (1905).

149. Bi-Metallic Inv. Co. v. State Bd. of Equalization, 239 U.S. 441 (1915).

150. For an excellent example of this trend, see Nathanson, The Vermont Yankee Nuclear Power Opinion: A Masterpiece of Statutory Misinterpretation, 16 SAN DiEgo L. REV. 183 (1979). 
formula devised to make these awkward decisions was little more than a conclusory assignment of traditional property and liberty interests to a private law category called "rights," while statutorily based, non-traditional interests were assigned to a category called "privileges."161 Thus were IM and SM hearing rights separated and their development rendered autonomous within their own assigned spheres.

\section{Implied Actions}

To sketch the doctrinal story of implied causes of action up to the passage of the APA we need note only three cases. The first is Texas \& Pacific Ry. v. Rigsby, ${ }^{152}$ which in 1916 recognized a right of action under the Federal Safety Appliance Act. But the basis of recognition was that the action fit within the individualist model. The Court's rationale was the already conventional notion of negligence per se:

A disregard of the command of the statute is a wrongful act, and where it results in damage to one of the class for whose especial benefit the statute was enacted, the right to recover the damages from the party in default is implied, according to a doctrine of the common law expressed . . . in these words: "So, in every case, where a statute enacts, or prohibits a thing for the benefit of a person, he shall have a remedy upon the same statute for the thing enacted for his advantage, or for the recompense of a wrong done to him contrary to the said law." This is but an application of the maxim, Ubi jus ibi remedium. [Where there is a right, there is a remedy.] ${ }^{153}$

Then came Erie R.R. v. Tompkins, ${ }^{154}$ which virtually eliminated the federal courts' role in the development of private law. Henceforth, if federal regulation were to provide the basis for a tort suit in federal court, the action would have to be reconceived as an action implementing the federal statute and, therefore, "arising under" federal law. The individualist-statist dichotomy was thus reinforced by notions of federalism imbedded in federal court jurisdiction.

Furthermore, in the new statist conception, statutory policy, not corrective justice, determined the recognition of rights. As the Court stated in the third case, Sola Electric Co. v. Jefferson Electric Co., ${ }^{155}$ in 1942:

When a federal statute condemns an act as unlawful, the extent and

151. See Van Alstyne, Cracks in "The New Property": Adjudicative Due Process in the Administrative State, 62 CORNELL L. REV. 445, 445-52 (1977).

152. 241 U.S. 33 (1916).

153. Id. at $39-40$ (citations omitted).

154. 304 U.S. 64 (1938).

155. 317 U.S. 173 (1942). 
Rights in the Administrative State

nature of the legal consequences of the condemnation, though left by the statute to judicial determination, are nevertheless federal questions, the answers to which are to be derived from the statute and the federal policy which it has adopted. ${ }^{158}$

The Court left further development of private law ideas of corrective justice by reference to federal statutory standards to the state courts.

\section{The New Deal and the Dual Legal Order}

The separation of individualist and statist areas of federal law, which is distinct in these doctrinal developments, tended to support and protect public authority from judicial meddling at the behest of individual claimants. It placed substantive policy, procedural requirements, and enforcement discretion firmly within congressional-administrative control. This dual legal system is the conceptual legacy of New Deal politics, which saw all too clearly the collapse of confidence in a private market structured and supported by an individualist conception of law. ${ }^{157}$ New Deal statutes provided new political institutions within which organized interests could support production and bargain about the distribution of the gains from productivity, as well as new programs of income support that would help maintain aggregate demand. ${ }^{168}$ The hegemony of IM thinking was overcome by restricting it to a private sphere that would not threaten these new institutions and programs.

\section{The Political Imperatives of the Sixties}

Thirty years later the political agenda had changed radically. Low productivity and anemic demand were no longer the problems that garnered political attention. The great domestic issues instead were limiting the damaging side effects of abundance, while producing a fairer distribution of the colossal wealth generated by post-war economic recovery. ${ }^{159}$ The need was not for institutions within which existing social groups could plan and bargain or which could implement programs of income security, but rather for institutions that would protect interests that had no groups. ${ }^{160}$

Moreover, the success of the courts in empowering largely unorganized blacks by creating justiciable civil rights suggested that judicial recognition

156. Id. at 176.

157. See T. ARNOLD, THE SYMBOLS OF GOVERNMENT (1935).

158. For general discussions of these issues, see C. BEARD \& H. SMITH, THE FUTURE COMES: A STUDY OF THE NEW DEAL (1933); NEW DEAL THOUGHT (H. Zinn ed. 1966).

159. See, e.g., R. CARSON, Silent SPRING (1962); M. HARRINGTON, THE OTHER AMERICA: PovERTY IN THE UNITED STATES (1962).

160. See Fiss, Groups and the Equal Protection Clause, 5 PHIL. \& PUB. AFF. 107, 147-56 (1976). 
of rights might play a creative rather than a stifling role in the emerging program of reform. Whereas courts had been the enemy of the New Deal, they were the allies of the Great Society. The "expert" and "flexible" agencies of the 1940's legal imagination, on the other hand, were now stodgy bureaus "captured" by special interests. ${ }^{\mathbf{1 6 1}}$

The volume 397 cases are, of course, a part of this political reform movement. If agencies give in to special interests, let those whose opportunities are reduced or whose risks are increased have a right to judicial review. If agencies are error prone, give those outsiders who have the facts a right to a hearing. If agency enforcement is lax, let those affected by wrongful conduct have a right to seek enforcement themselves. The conceptual problem was how to get from the separation of individualist and statist rights that had preserved the relative autonomy of administrative action from judicial intrusion to some new vision of rights that would utilize individual claims, judicial review, and private enforcement as components of a functional public law system.

Yet, as we have seen, the "rights" that were generated by judicial attempts at reconceptualization have turned out to be both limited in scope and fragile in use. The reason, I want to argue, is that the individualist and statist models have a certain general coherence. The various dimensions or aspects of each model fit together in a culturally understandable pattern. Reinterpreting one in terms of the other or borrowing techniques from one for the other will tend, therefore, to create special legal conceptions that have little analogical force. As courts address new questions, they will be driven, by their usual attempts to analyze the novel in terms of the familiar, to think in terms of the general models rather than of the hybrid forms. Creating a large number of hybrids having similar characteristics may, of course, yield a new general model, but that has not yet occurred.

Consider, therefore, the volume 397 cases as hybrids. What genes did they take from their individualist and statist parents? Goldberg first retains the individualist idea of property. To be sure, that idea is somewhat reinterpreted and cut loose from the peculiar notion that government grants could not provide a basis for property interests-an idea that hardly comports with the history of American land law or, indeed, with the feudal tenure system from which it has been derived. Property rights, as Goldberg conceives them, are claims to things having economic value, claims which are ubiquitous in traditional IM discourse. From SM it takes the idea that effectively implementing the property regime by proper

161. See, e.g., R. Fellmeth, The INTERSTATE COMMERCE OMISSION: ThE PUblic INTEREST AND THE ICC (1970); T. LOWI, THE END OF LIBERALISM (1969); G. STIGLER, THE CITIZEN AND THE STATE: ESSAYS ON REGULATION (1975). 
assignment of rights is pursuing a public interest. The opinion then melds these ideas into the requirement of an accuracy-seeking decision process that borrows heavily from the evidentiary techniques of judicial trial.

It follows from this description that Goldberg's hybrid right to a hearing will have little attraction where either element is missing, that is, where individually appropriable property is not at issue or where the function involved cannot be described as policy implementation through accurate fact-finding. ${ }^{102}$ In short, Goldberg contains no new general idea of participation by affected interests in administrative processes. It creates no general and justiciable right that can be played out across the myriad varieties of administrative functions and private interests.

The Supreme Court has thus (its grotesquely incompetent explanations aside) been quite consistent with Goldberg in rejecting attempts to turn government activities having a decidedly IM character, like employment contracts $^{183}$ and official torts, ${ }^{164}$ into government programs of policy implementation. And it has equally consistently resisted attempts to make general policy implementation into activities that implicate separably appropriable private property. ${ }^{165}$ Moreover, it has taken seriously the notion that the new property, like the old, has determinable attributes. Claims relating to some aspect of a public program bearing on, but not directly deciding, the allocation of a statutorily defined property interest are not appropriate occasions for Goldberg-style hearings. ${ }^{168}$ The Court has taken the public interest equally seriously. Hearings are not to be conferred as a right unless they would have a significant probability of enhancing accurate policy implementation. ${ }^{167}$

The components of the ADAPSO standing hybrid are fairly obvious. Injury in fact retains IM's realized-harm perspective. And it is this aspect of the ADAPSO test that has proven most limiting in subsequent application. The "arguably within the class of persons protected or regulated" formula takes an essentially statist perspective on the right-duty linkage. It abandons both the IM-oriented "especial benefit" formulation, commonly required for private law to recognize statutorily based rights of action, and the necessity that official actions run directly to or against a party to produce the requisite legal interest. The requirement is merely

162. Cf. O'Bannon v. Town Court Nursing Center, 447 U.S. 773 (1980) (determining suitability of Medicare provider without giving hearing to its residents); Board of Curators v. Horowitz, 435 U.S. 78 (1978) (determining adequacy of medical student's clinical progress without hearing).

163. See, e.g., Bishop v. Wood, 426 U.S. 341 (1976); Perry v. Sindermann, 408 U.S. 593 (1972); Board of Regents v. Roth, 408 U.S. 564 (1972).

164. See, e.g., Paratt v. Taylor, 451 U.S. 527 (1981); Paul v. Davis, 424 U.S. 693 (1976).

165. See United States v. Florida E. Coast Ry., 410 U.S. 224 (1973).

166. See O'Bannon v. Town Court Nursing Center, 447 U.S. 773 (1980).

167. See Board of Curators v. Horowitz, 435 U.S. 78 (1978). 
that the plaintiff be within the general framework of interests and responsibilities established by the statute-that he be recognized by the statutory scheme as at risk or as creating risks. ADAPSO thus generalizes the preAPA "adversely affected or aggrieved" idea to include legislative programs not employing that formulation in a specific judicial review provision.

The standing hybrid, unlike Goldberg's right to a hearing, is less easily rationalized as having been consistently applied in subsequent cases. Or perhaps, stretching the metaphor, one should view the ADAPSO formulation as having an unstable genetic composition. On the one hand, there occasionally has seemed to be a distinct possibility of metamorphosis into a purely statist conception. The SCRAP and Duke Power cases, for example, suggest that increased risk will satisfy the requirement of injury in fact, at least where the statutory scheme that gives rise to the complaint is itself essentially concerned with restructuring risks. In such a scenario, the probabilistic future effect of positive and negative incentives on the concrete situations of identifiable litigants would not inhibit judicial remedial action because remedies would be seen as oriented toward a class or group, rather than toward an individual. Indeed, recent developments in product liability law, like Sindell v. Abbott Laboratories, ${ }^{\mathbf{1 6 8}}$ suggest that the historical incarnation of IM thinking-the private law of tort-may be shifting its conception of the right-duty paradigm. ${ }^{169}$ And how long will IM be able to hold the legal imagination when its own foundations are unsettled?

Yet one should not get carried away when envisioning this developmental scenario. The plaintiffs in Sindell were not merely at risk; their cancers had appeared and were provably related to administration of the product. The only open question was whose product. Sindell may thus do for a corner of products liability law only what ADAPSO did for standing-broaden individual right-duty linkages to encompass group interestresponsibility relationships. It is, therefore, hardly a paradigm-shifting case that will pull injury-in-fact analysis into a new intellectual orbit.

168. 85 Cal. App. 3d 391, 149 Cal. Rptr. 138 (1978), vacated, 26 Cal. 3d 588, 163 Cal. Rptr. 132, 607 P.2d 924, cert. denied, 449 U.S. 912 (1980).

169. The shifting nature of the right-duty paradigm in product liability cases is best illustrated in the developing theories of alternative and enterprise liability. See id. While still requiring plaintiffs to establish an injury in fact and defendant's negligence, Sindell and its progeny have radically altered the nature of causation in product liability suits. These cases have dispensed with the concrete linkage between victim and wrongdoer, a principal characteristic of IM thinking. Indeed, plaintiffs may recover without ever alleging - much less proving - that defendant's negligence inflicted any demonstrable harm.

The most compelling, and most often invoked, justification for this departure from traditional tort notions of causation is the need for cost-spreading. As Justice Brennan has noted in a different context, "No longer is individual 'blameworthiness' the acid test of liability; the principle of equitable loss-spreading has joined fault as a factor in distributing the costs of [public] misconduct." Owen v. City of Independence, 445 U.S. 622, 657 (1980). 
Moreover, the Supreme Court's insistence in the standing cases that injury in fact, the traditional IM touchstone, is the constitutional bedrock for Article III standing hardly suggests a disposition to radically reorient standing doctrine without statutory authorization. Insistence on injury in fact may, to the contrary, suggest limitations on Congress' ability to further develop the statist model-at least in Article III courts.

There is also reason to believe that the post-ADAPSO prudential aspect of standing remains locked within the bifurcated structure ("suffering legal wrong"=IM; "adversely affected or aggrieved"=SM) ratified by the APA's standing provisions. For ADAPSO itself, when articulating the new standing test, distinguished between the pleading stage and the merits. And if on the merits plaintiffs must prove either that Congress meant to confer upon them an "especial benefit" or that they have been directly regulated, then nothing much has changed. The real standing question has merely been shifted from the pleading to the summary judgment stage of the litigation. Thus viewed, ADAPSO standing becomes an ephemeral as well as a hybrid legal doctrine. It may repeatedly sprout, bloom, and wither within the context of particular cases without changing the remedial gene pool specialized to pure IM and pure SM forms.

The bonding of public and private law notions in Rosado and Borak is rather more complicated. Although neither case makes much of the question, because on the facts it was easily answered affirmatively, both accept the traditional "especial benefit" formula for identifying whether a statutory rule of conduct can be made the basis for a private claim of right. Thus, the SM dimensions of the cases seem to predominate. The Borak court justifies its conferring the right, not on corrective justice grounds, but primarily because of the private action's potential contribution to effective enforcement of public policy. Indeed, it virtually has to do so. The conduct complained of could not be undone without significantly harming other innocent parties. And any damages awarded would surely have had little provable relationship to what the plaintiffs' position would have been absent the use of "misleading" proxy solicitations.

The Rosado opinion, as we noted previously, ${ }^{170}$ instructs district courts hearing similar claims to invite the participation of the responsible federal grant agency and, presumably, to defer to its expertise. Moreover, the Rosado court seems perfectly at ease with a remedial request that bears only an indirect and highly problematic relationship to any concrete change in the plaintiffs' circumstances. The Court explicitly notes that requiring revision of the AFDC standard of need only puts some marginal

170. See supra pp. 1134-36. 
political pressure on the state legislature to revise grant levels. ${ }^{171}$ But the opinion goes on to say that this restructuring of political incentives seems to be exactly what Congress had in mind when it adopted the standard of need requirement. ${ }^{172}$ The Court will enforce the congressional will whether or not it produces any concrete change in benefits levels because changing the chances of concrete changes is the purpose of the statute. Enforcing statutes that shift risks, not corrective justice, is the core of the judicial role in the statist model.

Post-Rosado doctrinal developments concerning implied causes of action may thus be seen as playing out the SM and IM paradigms in different strands of jurisprudence. The Borak-type cases have simply reinterpreted "especial benefit" to unite it with the public interest-statutory purpose basis for enforcement. Plaintiffs are entitled to the especial benefit of a cause of action on the statute only if it was the specific intent of the legislature to give it to them. In this way, the courts avoid interfering with legislative-administrative lawmaking and enforcement discretion and, more importantly, avoid the hopelessly difficult task of optimizing the level of public law enforcement through principled judicial elaboration of private rights and remedies. ${ }^{173}$

My suspicion is that Rosado-style actions have moved and will continue to move in a similar direction. If the Court takes seriously the SM ideas of welfare-enhancing enforcement levels and the complex interconnections of subsidies and sanctions imbedded in inter-governmental politics, then it is likely to produce more Pennhurst and Sea Clammers decisions. Particular instances of litigation involving claims of individual right and duty simply will not provide an appropriate context for exercising the broad managerial and political discretion these issues demand. As in the securities law arena, the Court may well not overturn substantial lines of authority providing enforcement rights in specific programs. But over time these exceptions may come to seem about as sensible as the apparently permanent idea that professional baseball is not commerce for purposes of the antitrust laws. ${ }^{134}$ (George Steinbrenner must pray nightly at the shrine of stare decisis.)

On the other hand, where cases are of the " $A$ wrongfully hit $B$ and should pay damages" sort, in other words, constitutional torts, the Court is quite happy to develop causes of action by analogy to the private law. These cases doubtless have some special features because constitutional

171. Rosado v. Wyman, 397 U.S. 397,413 (1970).

172. Id. at 414-15.

173. See Polinsky \& Shavell, The Optimal Trade-off Between the Probability and Magnitude of Fines, 69 AM. ECON. REV. 880 (1979) (developing complex econometric model).

174. Flood v. Kuhn, 407 U.S. 258 (1972). 
rights and official defendants are involved. In conventional legal parlance, we would call them "public law" cases. But, in fact, they respond conceptually to the individualist model that has its roots in traditional private law. Within that model, justiciability is relatively non-problematic.

VIII. Idealism and the Sorry Gondition of Rights

The foregoing account surely has some plausibility and appeal. It begins to make sense of doctrinal developments that seem rather hopelessly confused and confusing. It puts the volume 397 cases-proxies for the creative legal period of the 1960's and the early 1970's-in some perspective. Yet this story. may be viewed nonetheless as highly unsatisfactory from at least two viewpoints. First, its emphasis on the gravitational pull of intellectual models seems a throwback to pre-Realist legal conceptualism, an exaltation of the logic over the life of the law. Second, the analysis tends to ratify an impoverished conception of justiciable rights. Many might argue that what is needed is not an apology for this sorry state of affairs, but a new conception integrating the protection of individual rights with the pursuit of collective ends.

To the first objection, I must surely plead nolo contendere, if not in flagrante delicto. But let me only add a bit of avoidance to this confession. There is no argument here that these intellectual currents are autonomous. Indeed, we have viewed them as connected historically to changes in our collective political and institutional life. What is missing is either (1) a description of the mechanism by which the ideas can be mapped onto the social reality, or (2) a general proof of the apparent assumption that operating at the level of legal concepts will not seriously misrepresent legal dynamics. At this point I can say only that, although far from accomplishing the task, I do not despair that either of these methodologically necessary components of a resuscitated legal conceptualism might be provided. For I believe both that art mimics life and that life mimics art.

As to the second count of the indictment, I want to claim that there has been no offense. For we would need no new conceptions of justiciable legal rights if we believed either that our present ones were working reasonably well or that reform in the "rights" direction (meaning more hearing rights, more judicial review, and more implied rights of action) would misdirect our energies. In part, it seems to me, both of these conditions obtain. I will say why I think so very briefly, for I have no exclusive claim to your attention or to the Law JournaPs printing budget.

First, the hearing rights that the courts have recognized following Goldberg and preserved in later cases ${ }^{175}$ are far from insignificant. These

175. The large number of cases applying Goldberg hearing rights within five years of that deci- 
rights approximate the legal security available for more traditional forms of property. The judicial recognition that state programs may be oriented precisely to redistributional goals that can succeed only by creating "new property" interests-interests responding largely to the individualist model of rights-is a major improvement over older IM notions, which threatened to exclude legislative entitlements categorically from the domain of recognizable property interests. That the Court does not perceive the state as always engaged in this kind of redistributional activity is hardly cause for alarm.

We should not forget, moreover, that most federal statutes (and their implementing regulations) themselves provide for hearings structured to conform to the types of programs, issues, and interests at stake in administrative decisionmaking. ${ }^{178}$ There is, in fact, a broad range of "hybrid" procedures that confer both rights to participate and reasonable security of expectations to those affected by federal action. ${ }^{177}$ Judicial reluctance to proceduralize does not make the development of appropriate decisional models for the administrative state stagnant. Furthermore, as Professor Simon's paper ${ }^{178}$ (in addition to an already substantial critical literature) suggests, "privatizing" of entitlement through adjudicatory protection mechanisms may have complicated and untoward dynamic effects, even in those cases where the IM perspective seems most appropriate.

Legislative creativity is similarly evident with respect to standing and private enforcement proceedings. The general, structural legislation of the 1960's and 1970's (for example, FOIA, ${ }^{179}$ the Privacy Act, ${ }^{180}$ and $\mathrm{NEPA}^{181}$ ) and the major new organic regulatory statutes (FWPGA, ${ }^{182}$ the

sion are collected and discussed in Rendleman, The New Due Process: Rights and Remedies, 63 KY. L.J. 531 (1975); see Friendly, "Some Kind of Hearing," 123 U. PA. L. REV. 1267 (1975); Griswold, The Due Process Revolution and Confrontation, 119 U. PA. L. REV. 711 (1971).

176. Statutes commonly require a "hearing," "hearings," or an "opportunity to be heard." See, e.g., Federal Water Pollution Control Act Amendments of 1972, § 2, 33 U.S.C. § 1312(b)(1) (1976) (Administrator must "hold a public hearing"); Clean Air Act Amendments of 1977, § 305a, 42 U.S.C. $\S 7607$ (d)(5)(ii) (1976) ("Administrator shall give interested persons an opportunity for the oral presentation of data, views, or arguments . . . ."); see $1 \mathrm{~K}$. DAVIS, ADMINISTRATIVE LAW TREA. TISE, $\$$ 6:22 to 6:24 (2d ed. 1978).

177. Federal Trade Commission Improvement Act of 1974, § 8a, 15 U.S.C. § 57a(b) (1982); Occupational Safety and Health Act of 1970, § 6, 29 U.S.C. $\S$ 655(b) (1982); Consumer Product Safety Act of 1972, § 9, 15 U.S.C. § 2058 (1982); Toxic Substances Control Act of 1976, § 6, 15 U.S.C. $\$ 2605$ (c) (1982); see Hamilton, Procedures for the Adoption of Rules of General Applicability: The Need for Procedural Innovation in Administrative Rulemaking, 60 CALIF. L. REV. 1277 (1972).

178. Simon, Legality, Bureaucracy, and Class in the Welfare System, 92 YALE L.J. 1198 (1983).

179. Freedom of Information Act of 1974, 5 U.S.C. $\S 552$ (1982).

180. Privacy Act of 1974, 5 U.S.C. $\$ 552 \mathrm{a}$ (1982).

181. National Environmental Policy Act of 1969, 42 U.S.C. $\$ \S 4321-4361$ (1976 \& Supp. V 1981).

182. Federal Water Pollution Act Amendments of 1977, 33 U.S.C. $§ \S 1251-1376$ (1976 \& Supp. V 1981). 
Clean Air Act, ${ }^{183}$ OSHA, ${ }^{184}$ and CPSA, ${ }^{185}$ for example) are highly attentive to questions of standing and citizen enforcement as well as procedurally and institutionally innovative. Only extreme judiciocentricity would cause us to imagine that the citizens of the administrative state are playing a shrinking role in federal policy formation and implementation. The change is that the creative role in orchestrating state-citizen encounters is being played by the preeminently statist-oriented institutions.

This institutional reorientation is, I think, the contemporary legal significance of the New Deal. That era of intensely pragmatic problem-solving sought primarily to do three things: to provide a new legal framework for labor-management relations, to restructure business competition to eliminate its potential to destroy rather than create productive capacity, and to redistribute and maintain purchasing power by cushioning a range of individual risks that restrict labor market participation. In the process of accomplishing these tasks, the New Deal reformers provided us with a set of legal institutions and legal categories that have partially shaped what I have called the statist model of rights.

The legislative changes that have taken place since that time reinforce rather than reject these ideas. The civil rights movement, environmentalism, and consumerism move beyond groups to interests, not back towards individualism. The causal paradigm of macroeconomics that so informed New Deal thinking and programs is deepened and extended by the epidemiological and ecological models that inform contemporary health and safety legislation. Legislation and administrative regulation have proliferated along with an increasingly systemic, managerial, and professional perspective on the development and implementation of public policy.

If these developments concern us, if we distrust legislative-administrative machinery and revere market mechanisms, or if we chafe at the failure of the state apparatus fully to protect collective interests in economic security, public health and human dignity, we would do well to address these issues as issues of politics, not as a judicial failure to produce effective conceptions of rights. The statist model of rights seems both epiphenomenal and generally appropriate to the administrative state that we have developed. Moreover, it reminds us of a truth that no architect of New Deal public policy was likely to forget: If we do not like the rights that state organizational imperatives produce, we must change the organization of the state.

183. Clean Air Act Amendments of 1977, 42 U.S.C. $\$ \S 7401-7642$ (1976 \& Supp. V 1981).

184. Occupational Safety and Health Act of 1970, 29 U.S.C. $\$ \S 651-678$ (1982).

185. Consumer Product Safety Act, 15 U.S.C. $\S \S 2051-2081$ (1982). 